\title{
VÝSKUMY ARCHEOLOGICKEJ EXPEDÍCIE UŽHORODSKEJ NÁRODNEJ UNIVERZITY NA HRADOCH V ZAKARPATÍ
}

\author{
IGOR PROKHNENKO - MARIA ZHYLENKO
}

\begin{abstract}
Abstrakt: V roku 2007 vznikla skupina stredovekej archeológie pri archeologickej expedicii Užhorodskej národnej univerzity zameraná na štúdium hradov v Zakarpatskej oblasti Ukrajiny. Skúmali sa viaceré hrady, z ktorých neboli predtým známe žiadne archeologické pramene (Vynohradiv, Korolevo, Bronka, Seredné, Silce a Kvasovo). Archeologický prieskum bol vykonaný aj v lokalite susediacej s kaštielom $v$ Činadieve.
\end{abstract}

Kl'účové slová: stredovek - včasný novovek - hrad - kaštiel' - stratigrafická situácia.

Research of the archaeological expedition of Uzhhorod National University into Transcarpathian castles

\begin{abstract}
A medieval archaeology group was established in 2007 for the purpose of an archaeological expedition of Uzhhorod National University. It focused on the study of castles in the Transcarpathian area of the Ukraine. The expedition investigated several castles from which no previous archaeological sources were known (Vynohradiv, Korolevo, Bronka, Seredne, Silce and Kvasovo). Archaeological research was also conducted on a site close to the castle in Cinadieve.
\end{abstract}

Key words: Middle Ages - early modern age - castle - stratigraphic situation.

V historiografii venovanej stredovekej a včasnonovovekej vojenskej architektúre Horného Potisia boli zaznamenané viac ako dve desiatky hradov umiestnených na území súčasnej Zakarpatskej Ukrajiny. Ich zapojenie do historickej rekonštrukcie čelí určitým t’ažkostiam, počínajúc definíciou pojmu „hrad“, ktorý zvyčajne zahŕňa hradiská (,zemné pevnosti“), kaštiele a hliadkové veže. $\mathrm{V}$ dôsledku toho sa do vedeckého povedomia zaviedlo množstvo neistých lokalít. Týka sa to najmä kaštiel'ov v Činadieve (mad'. Szentmiklós, Beregszentmiklós), Dovgom (slov. Dlhé, mad'. Dolha, Hosszúmezö), Eseni (mad'. Eszeny) a Gorianach (slov. Horiany, mad'. Gerény), ako aj presne nelokalizovaných sídlisk Beregvár, Gutivár, Sásvár a lokalít bez kamenných opevnených budov (Didovo-Tóvár, Boržava, mad'. Borzsova, a Vyškovo, mad’. Visk, rum. Văşcova). Po ich vylúčení zo všeobecného zoznamu je možné medzi spol’ahlivé lokality zaradit’ Bronku (Cárska hora; mad'. Szuhabaranka, Baranka), Vynohradiv (Kankiv, slov. Sevl'uš, Vinohradovo, mad'. Nagyszőlős), Kvasovo (mad'. Kovászó), Korolevo (mad’. Királyháza, Nyaláb), Mukačevo (mad'. Munkács, Palanok), Nevicke, Silce (Boduliv), Seredne (mad'. Szerednye), Užhorod (mad'. Ungvár) a Chust (mad'. Huszt) (obr. 1).

Tieto hrady sú umiestnené $\mathrm{v}$ páse, ohraničenom predhorím Karpát a hlavnými vodnými tepnami oblasti. Čas vzniku väčšiny z nich ako včasnostredovekých hradov, spravidla bez riadnej argumentácie, sa v literatúre datuje do 9.-10. storočia a prestavba do kamennej podoby do 11.-12. storočia. Takéto datovanie kl’účových pamiatok sa nezhoduje s obdobím vzniku podobných kamenných opevnení v severovýchodnej časti Karpatsko-dunajského regiónu. Ich počiatky sú spravidla kladené do obdobia druhej polovice 13. až prvej polovice 14. storočia (ПрохненкоГомоляк 2009, 71-97; Прохненко-Гомоляк-Зомбор 2009, 239-260).

V tejto situácii, s ciel'om riešit' otázky chronológie a najmä stanovit' čas výstavby hradov v Zakarpatí, vznikla potreba kritickej analýzy písomných prameňov a venovat' väčšiu pozornost' archeologickým prameňom. Tento stav určil pracovné zameranie stredovekej skupiny archeologickej expedície Užhorodskej národnej univerzity vytvorenej v roku 2007. Išlo najmä o výskum tých hradov, z ktorých chýbali archeologické pramene. Išlo o hrady Vynohradiv, Korolevo, Bronka, Seredne, Silce a Kvasovo. Menšie práce boli vykonané aj na lokalite susediacej s kaštiel’om v Činadijeve. Hlavným ciel’om prvej fázy výskumu je získanie stratifikovaných nálezov, vytvorenie schém pre relatívnu a absolútnu chronológiu pamiatok. 


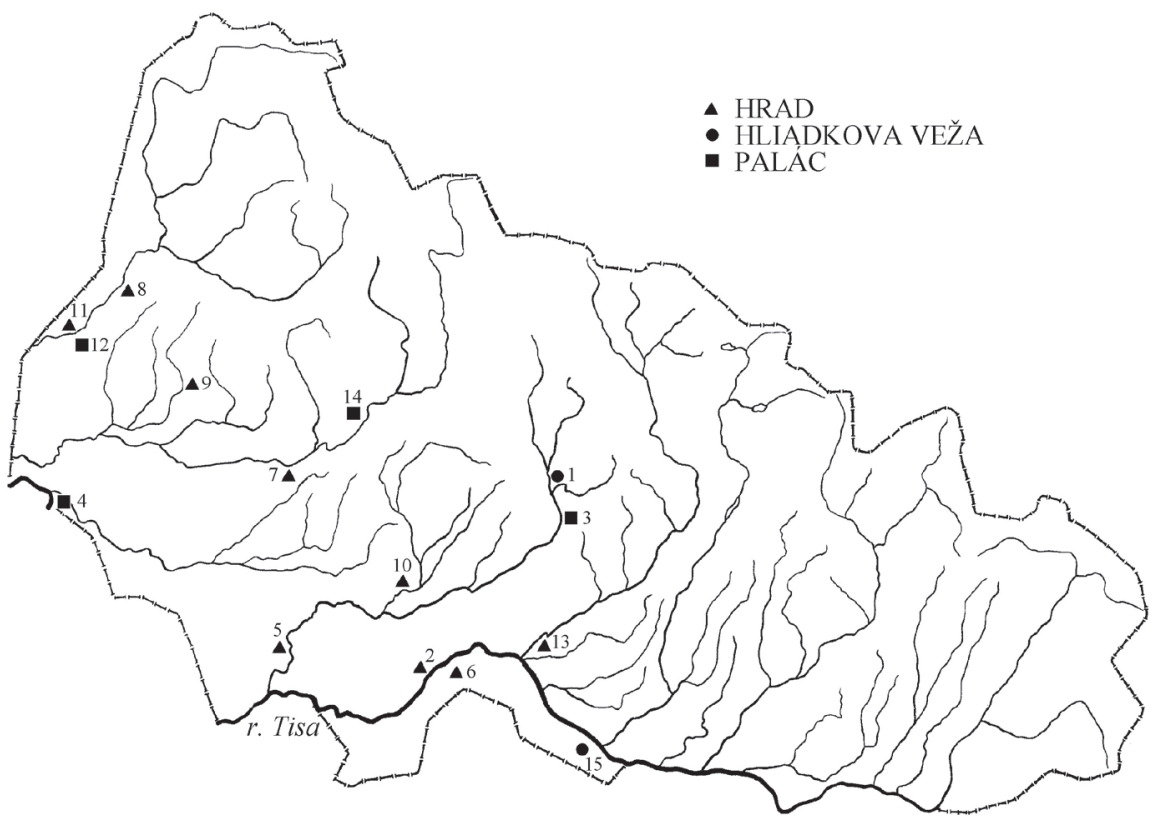

Obr. 1. Mapovanie hradov, hliadkových veží a kaštiel’ov umiestnených na súčasnom území Zakarpatskej oblasti Ukrajiny. 1 - Bronka (Cárska hora; mad'. Szuhabaranka, Baranka); 2 - Vynohradiv (Kankiv, slov. Sevl'uš, Vinohradovo, mad'. Nagyszőlős); 3 - Dlhe (slov. Dlhé, mad'. Dolha, Hosszúmező); 4 - Esen (mad'. Eszeny); 5 - Kvasovo (mad'. Kovászó); 6 - Korolevo (mad'. Királyháza, Nyaláb); 7 - Mukačevo (mad'. Munkács, Palanok); 8 - Nevicke; 9 - Seredne (mad'. Szerednye); 10 - Silce (Boduliv); 11 - Užhorod (mad'. Ungvár); 12 - Užhorod-Horiany (slov. Horiany, mad'. Gerény); 13 - Chust (mad'. Huszt); 14 Činadieve (mad'. Szentmiklós, Beregszentmiklós); 15 - Vyškovo (mad’. Visk, rum. Văşcova).

Fig. 1. Castles and watchtowers in the present-day territory of Transcarpathian Ukraine. 1 - Bronka (Cárska hora; in Hungarian Szuhabaranka, Baranka); 2 - Vynohradiv (Kankiv, in Slovak Sevl'uš, Vinohradovo, in Hungarian Nagyszőlős); 3 - Dlhe (in Slovak Dlhé, in Hungarian Dolha, Hosszúmező); 4 - Esen (in Hungarian Eszeny); 5 - Kvasovo (in Hungarian Kovászó); 6 - Korolevo (in Hungarian Királyháza, Nyaláb); 7 - Mukachevo (in Hungarian Munkács, Palanok); 8 - Nevicke; 9 - Seredne (in Hungarian Szerednye); 10 - Silce (Boduliv); 11 - Uzhhorod (in Hungarian Ungvár); 12 - Uzhhorod-Horiany (in Slovak Horiany, in Hungarian Gerény); 13 - Chust (in Hungarian Huszt); 14 - Činadieve (in Hungarian Szentmiklós, Beregszentmiklós); 15 - Vyškovo (in Hungarian Visk, in Romanian Văşcova).

V roku 2007 boli vybrané ako prvé skúmané lokality vo Vynohradive a Korolevský hrad (Vinohradivský okres). Vynohradivský hrad sa nachádza v lokalite Kankiv na juhovýchodnom okraji mesta Vinohradiv (do roku 1946 nazývané Sevl'uš) na úpätí Čiernej hory, ktorej opačný svah obmýva rieka Tisa. Opevnenie má štvoruholníkový pôdorys s vystupujúcimi nárožiami $(44,5 \times 35$ m) a s vnútornou obvodovou zástavbou. Ohraničovala obdížnikové nádvorie (obr. 2). Okrem hradných stavieb architektonický súbor tvorila kaplnka severozápadne od hradu a juhovýchodne od neho kostol (obr. 3). Celý stavebný komplex bol obklopený vonkajším kamenným múrom, ktorý je v súčasnosti pozorovatel'ný iba na niekol'kých menších úsekoch.

V odbornej literatúre je história hradu predstavená ako nepretržitý ret’azec udalostí od 9. po 16. storočie (výstavba, prestavba, výmeny majitel'ov a držitel'ov, zničenie a zánik). Väčšina $\mathrm{z}$ uvedených udalostí však nemá oporu v písomných prameňoch a niektoré uvádzané údaje si dokonca protirečia. Kritický prístup k pramennej báze umožňuje stanovit' osnovu hlavných udalostí spojených s hradom. Prvá písomná zmienka o Sevl’uši sa datuje do roku 1280 (ÁUO XII, 291). V roku 1307 král' Karol Róbert daroval mestečko komorníkovi Beke Borsa z rodu 


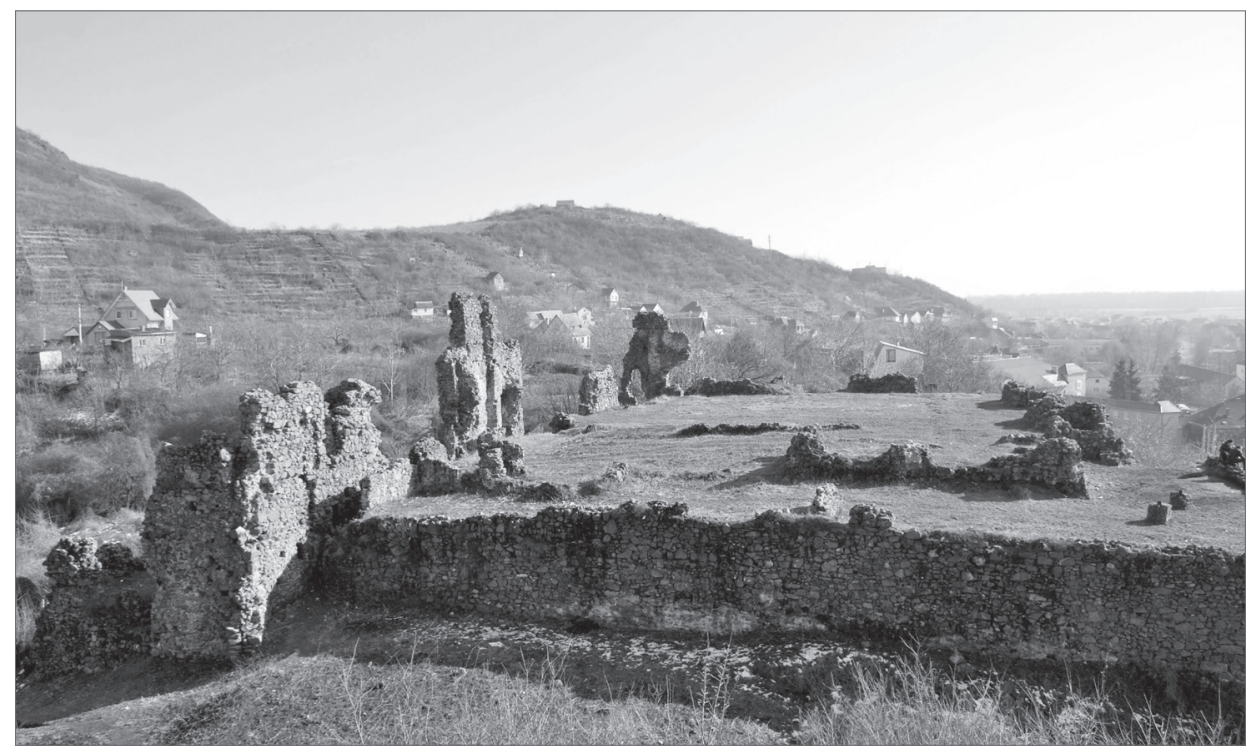

Obr. 2. Vynohradivský hrad Kankiv, Vynohradivský okres.

Fig. 2. Vynohradiv castle Kankiv, Vynohradiv district.

Tamásfy (AO I, 124). Pravdepodobne spolu s mestečkom získal aj povolenie na vybudovanie pevnosti, ktorej kastelán sa po prvýkrát objavil v prameňoch z roku 1308 (AO I, 138). Po tom, čo sa Borsovi bratia stali spojencami Matúša Čáka proti král’ovi Karolovi Róbertovi, na hrad zaútočil a vrátil ho do vlastníctva koruny berežský župan Tamás Jánky (A Perényi, 24-25). Počas útoku bol obranný systém pevnosti zničený. Do roku 1399 mesto patrilo královnej, ale hrad sa už v žiadnych dokumentoch nespomína (Fügedi 1977, 201).

Na prelome 14.-15. storočia král' Žigmund daroval Sevl'uš sekel'skému a zemplínskemu županovi Petrovi Perényimu za jeho vernú službu (A Perényi, 206-207). Spolu s darovacou listinou Perényi získal aj povolenie na výstavbu hradu, ale nestihol ho využit' (Zsk. I, 6111). O niekol'ko rokov mu bolo darované Nyalabské panstvo s centrom v Korolivskom hrade, takže potreba výstavby nového hradu sa stala neaktuálnou. Na území určenom na výstavbu opevnenia bol približne v roku 1505 postavený františkánsky kláštor (Riskó 2007, 29), ktorého patrónmi boli Perényiovci. Kláštorný komplex fungoval približne polstoročie. Situácia sa zmenila v roku 1556, ked' František Perényi, vychovaný v reformovanej tradícii, rozohnal mníchov a zničil kláštor (Rupp 1872, old. 393), ktorý po týchto udalostiach už nebol obnovený.

S ciel’om overit' chronologický vývoj a stratigrafické pomery lokality sa tu počas výskumnej sezóny v roku 2007 urobilo pät' zist'ovacích sond s celkovou výmerou $29 \mathrm{~m}^{2}$ (obr. 3). Tri z nich $(2 \times 3 \mathrm{~m})$ v rámci hradu, jedna $(2 \times 2,5 \mathrm{~m})$ v kaplnke a d’alšia $(2 \times 2,5 \mathrm{~m})$ na ploche kostola (Прохненко-Гомоляк 2007, 83-94).

Sonda 1 bola na severozápadnej strane nádvoria hradu, pri vnútornej stene obvodovej zástavby. Počas výskumu bola zachytená nasledujúca stratigrafia: vrchná vrstva s mocnostou $0,2 \mathrm{~m}$ pozostávala $\mathrm{z}$ výrazne utlačenej sivej hliny, pod ktorou bola vrstva $(0,2-0,4 \mathrm{~m})$ zeminy hnedej farby. Jej podklad tvorila vrstva žltého štrku hrubá až $0,2 \mathrm{~m}$, a pod ňou sa objavila vrstva podobná vyššie zistenej hnedej hline. V juhovýchodnom profile sondy bol v híbke $0,7 \mathrm{~m}$ zachytený zhluk kameňov, zmiešaný $\mathrm{s}$ vápennou maltou a pieskom s hrúbkou $0,1-0,2 \mathrm{~m}$. Vrstva kameňov klesá smerom k severozápadnému profilu, k ohnisku umiestnenému pod stenou, pri ktorej bola umiestnená sonda. V juhovýchodnej časti sondy pod závalom kameňov v híbke $0,65 \mathrm{~m}$ bola zistená koruna muriva, tvoriaceho roh budovy, ktorý sa nachádzal v híbke $1 \mathrm{~m}$. Hornú čast' muriva 


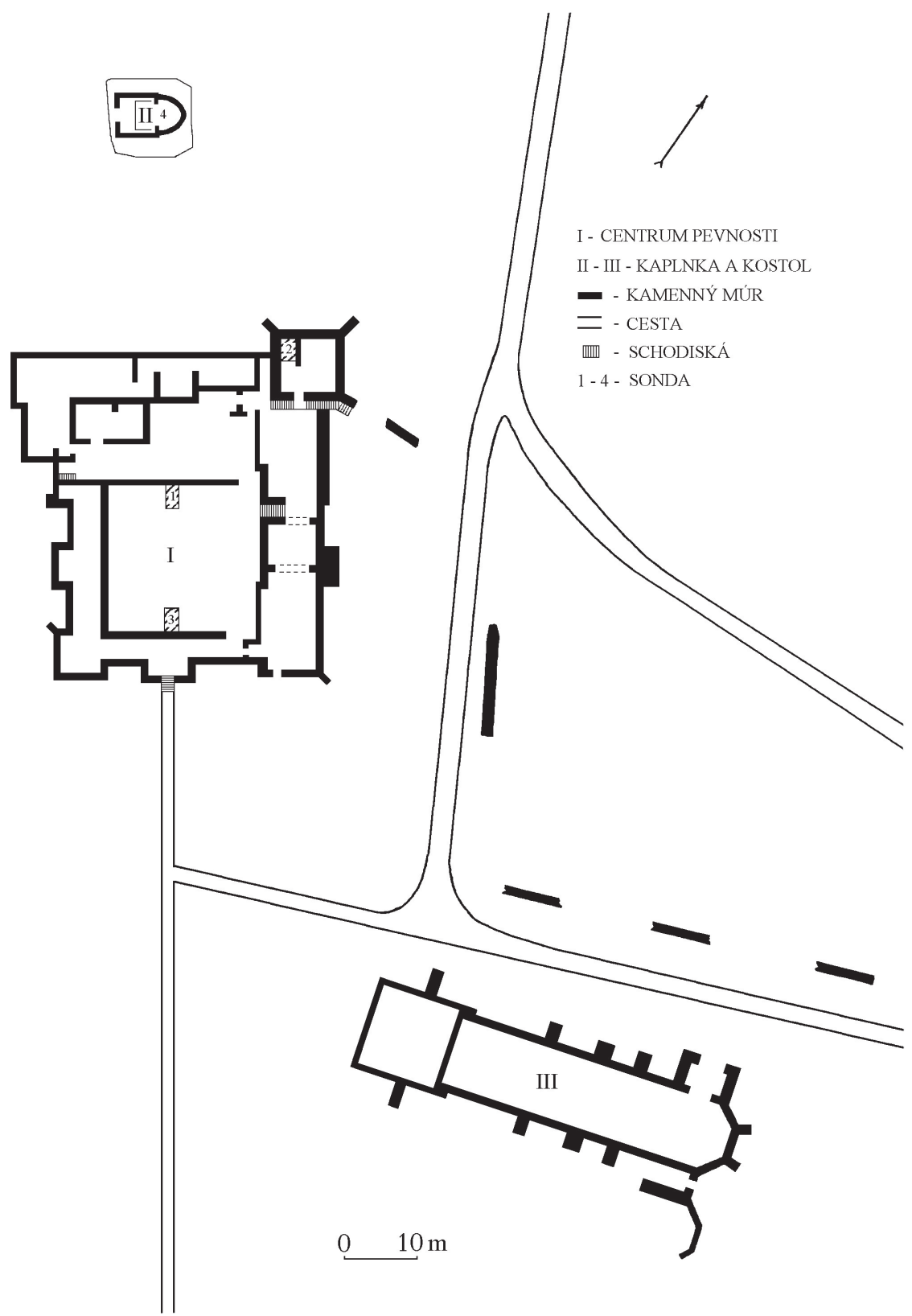

Obr. 3. Pôdorys Vynohradivského hradu Kankiv.

Fig. 3. Plan of the Vynohradiv castle Kankiv. 
a čast' pod ohniskom fixovala vrstva zavalených kameňov, pod ktorými boli vrstvy tmavosivej zeminy (od 0,7 / 0,85 do 1,1 m) a žltej hliny (1,1-1,7 m). Posledná leží na skalnom podloží.

Sonda 2 orientovaná v smere severozápad-juhovýchod bola umiestnená v západnom rohu severnej veže. V sonde sú sypké vrstvy, ktoré pravdepodobne vznikli ako stavebný odpad a stavebná deštrukcia. Dominantnými nálezmi je v ruke modelovaná keramika z neskorej bronzovej doby. Stredoveké a včasnonovoveké nálezy datujeme do 15.-16. storočia a sú zastúpené iba malým počtom zlomkov hrncov, železných klincov a zlomkami kamenného ostenia okna.

Na spresnenie stratigrafickej situácie sledovanej v sonde 1 vo vzdialenosti $14 \mathrm{~m}$ smerom na juhovýchod od nej, pri protil'ahlej stene vnútorného nádvoria bola vytýčená sonda 3. Podobne ako predchádzajúce sondy bola orientovaná zo severozápadu na juhovýchod. Zistila sa nasledovná stratigrafická situácia: do híbky $0,6-0,7 \mathrm{~m}$ tu bola uložená vrstva sivej hliny so zvyškami vápna a omietky. V jej obsahu, s výnimkou zlomku dna hrnca pokrytého glazúrou, bola zistená výlučne ručne tvarovaná keramika kultúry Suciu de Sus. Hlbšie ležala vrstva tmavosivej hliny. Z objektov sa zistila jama hruškovitého tvaru, ktorá bola vyplnená silne utlačenou hlinou tmavosivej farby $\mathrm{s}$ vel'kým obsahom $\mathrm{v}$ ruke modelovanej keramiky.

Ďalšia sonda (sonda 4) bola vytýčená v západnom rohu kaplnky. Kaplnka sa nachádza 30 m severozápadne od hradu. Pri nevýznamnej ploche kaplnky je zaujímavé to, že jej základ má štvorcový tvar a dosahuje hrúbku 3,5 m. V priebehu výskumu sondy bola sledovaná nasledujúca stratigrafická situácia: vrchná vrstva v niektorých miestach dosahovala mocnost' až do $1 \mathrm{~m}$ (čo je zapríčinené moderným prekopaním). Nižšie do híbky $2,9 \mathrm{~m}$ po celej sonde sú zaznamenané vrstvy deštrukcie z vel'kých andezitových kameňov a malty. Boli zistené aj časti zničených a do stredu zvalených múrov budovy. Deštrukcia ležala na vrstve humusovej hliny s malým obsahom keramického materiálu.

Zistená situácia umožňuje vyslovit' záver, že kaplnka bola postavená na mieste čiastočne zničenej veže. Pri rozoberaní stien bola jej vnútorná čast' zasypaná kameňmi. Táto prekrytá vrstva a nálezy zlomkov hrncov z jej obsahu stanovujú čas založenia veže v prvej polovici 14. storočia

Zvlášt' je potrebné spomenút' sondu v západnej časti kostola. Jej zásyp pozostával zo zlomkov glazovanej keramiky a stavebného odpadu zmiešaného s l'udskými pozostatkami, ktoré sa nachádzali v híbke od 0,1 do $2 \mathrm{~m}$. Charakter vrstvy nedovol'uje určit' dátum výstavby kostola a preskúmat' stratigrafiu pamiatky po celom úseku.

Analýza nálezov získaných v roku 2007 sa stala základom pre nasledujúci stratigrafický obraz Vynohradivského hradu. Počiatočné osídlenie lokality je datované do 14.-12. storočia pred n. 1. a je spojené s nositel'mi kultúry Suciu de Sus. To, že pamiatka je umiestnená na vyvýšenine, ju umožňuje považovat' za bod prirodzene opevnený horskými svahmi. V súčasnosti nie je možné identifikovat' fortifikačné systémy neskorej doby bronzovej, ktoré boli zničené počas stavebných prác v stredoveku. Výstavba systému kamenných opevnení sa datuje do 14. storočia. Obnovenie fortifikačných systémov bolo vykonané v 16. storočí, ale je potrebné poznamenat', že na preskúmaných častiach pamiatky sú stredoveké a včasnonovoveké horizonty slabo zastúpené (obr. 4).

Vo vzdialenosti $10 \mathrm{~km}$ od Vynohradivského hradu sa nachádza Korolivský hrad. V súčasnosti je jednou z najlepšie preskúmaných pamiatok na Zakarpatskej Ukrajine z obdobia neskorého stredoveku a včasného novoveku. Hrad je známy aj pod názvom Nyaláb. Nachádza sa na severozápadnom okraji obce Korolevo (Vynohradivský okres; obr. 5). Výška hradného kopca je $52 \mathrm{~m}$. Z vrcholu je dobrý výhl'ad na údolie rieky Tisa, ktorá tečie 300 metrov od úpätia. Jadro hradu $\mathrm{s}$ rozlohou $52 \times 47 \mathrm{~m}$ má v pôdoryse približne oválny tvar a nachádza sa v severozápadnej hornej časti hradného kopca. Obytné budovy umiestnené pozdĺž obvodu obklopujú malé vnútorné nádvorie so studňou (obr. 6). Ďalšia ochranná línia s budovou obdížnikového tvaru sa nachádzala 20 m od hlavnej hradnej budovy. Systém opevnení spájal most, postavený na mohutnom kamennom pilieri s oblúkovou klenbou v strede. Dodatočnú ochrannú líniu obklopovala priekopa. Pre kontrolu zemnej cesty - jediného pohodlného prístupu k hradu, bola na juhovýchodnom okraji lokality postavená klinovitá bašta. 

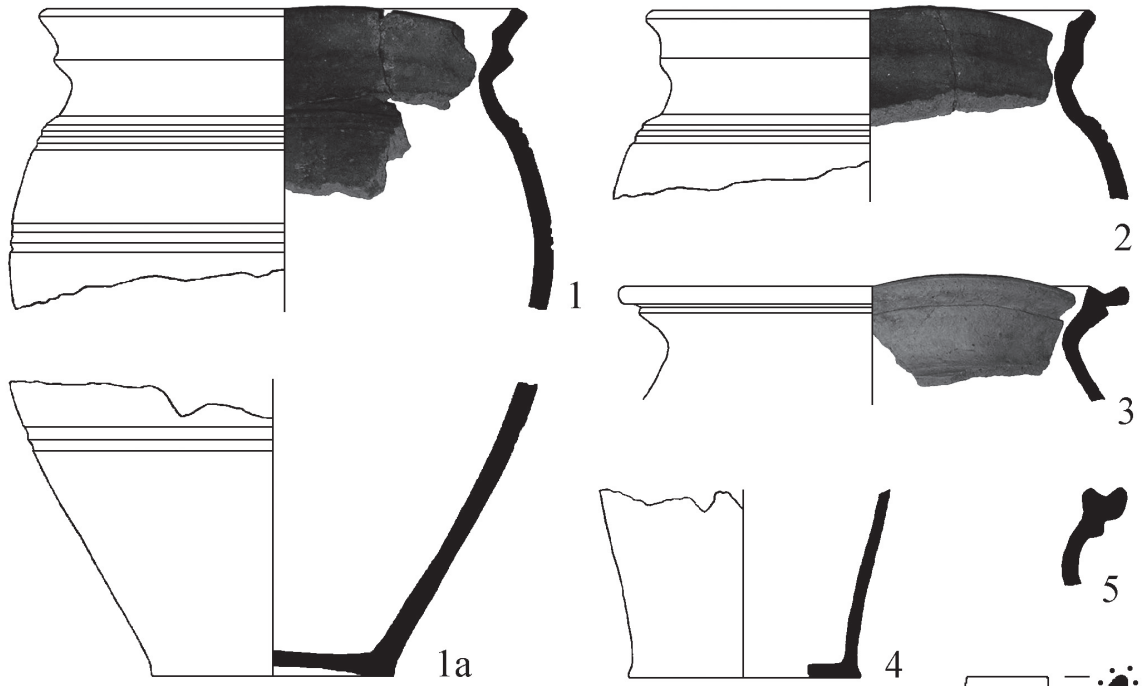

4
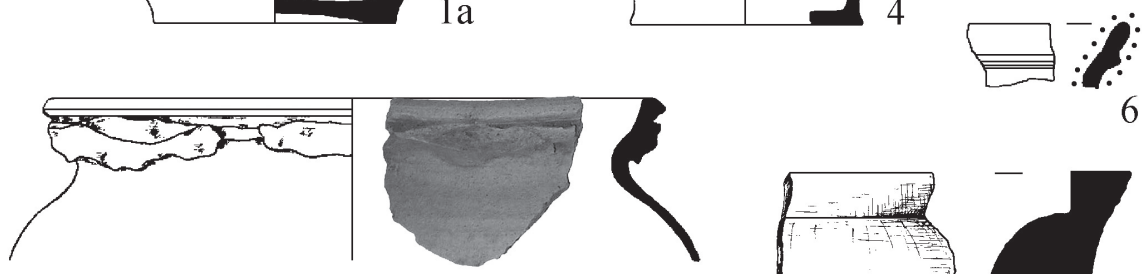

6
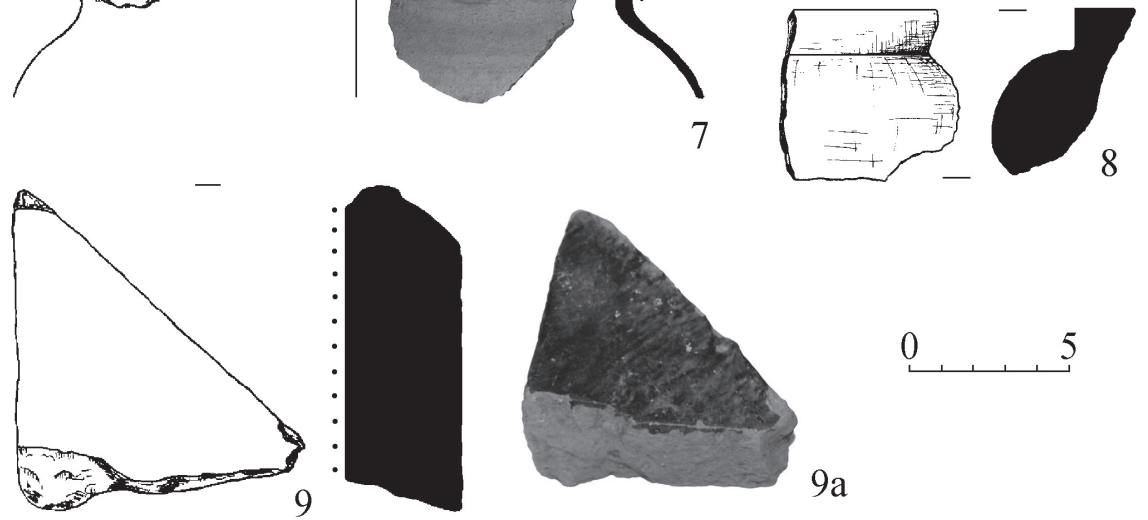

0

5

Obr. 4. Keramické nálezy Vynohradivského hradu Kankiv.

Fig. 4. Pottery finds from the Vynohradiv castle Kankiv.

Písomné pramene dokladujú využívanie pevnosti na severovýchodnom okraji Uhorského král’ovstva od konca 13. až po tretiu štvrtinu 17. storočia. Pred výstavbou opevnenia sa v blízkosti obce Felsás (prvý názov Koroleva) uvádza existencia loveckého dvora (domus regalis), ktorý sa naposledy spomína v roku 1272. Hrad sa však v prameňoch objavuje až od roku 1315 (HO, 193).

Na začiatku 14. storočia král' Karol Róbert daroval hrad král’ovskému komorníkovi Beke Borsa (Karácsonyi 1900, 211). Po tom, ako posledný držitel’ prešiel na stranu Matúša Čáka, hrad obsadil a z ruín obnovoval berežský župan Tomás (A Perényi, 24, 25).

V roku 1378 král' L’udovít I. spolu s funkciou župana ugočskej župy odovzdal Nyaláb do používania „pro honore“ moldavskému šlachticovi Dragovi a jeho bratom. Počas ich panovania 


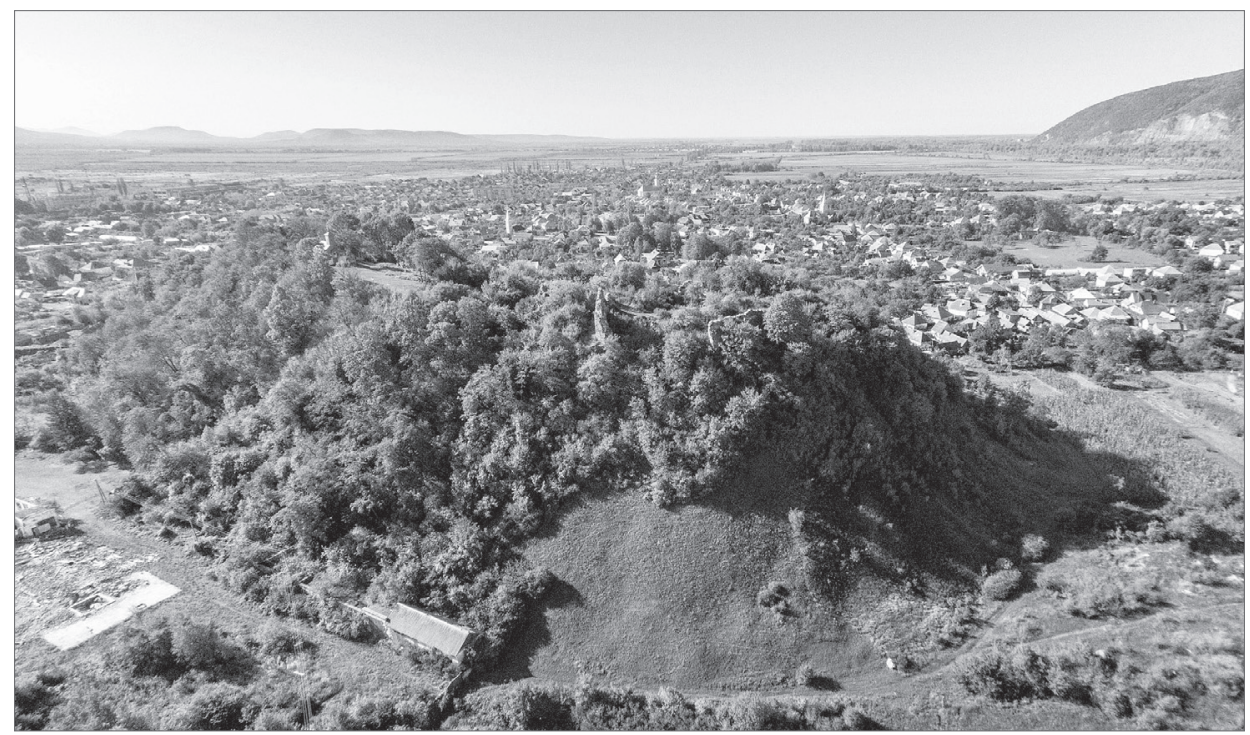

Obr. 5. Korolivský hrad Nyaláb, Vynohradivský okres.

Fig. 5. Korolevo castle Nyaláb, Vynohradiv district.

sa domínium nielen výrazne rozšírilo, ale stalo sa aj lokálnym centrom, čo dokladuje prepísanie Evanjelia do slovanského jazyka na hrade Nyaláb v roku 1401 (Микитась-Чучка 1968, 62-64).

V roku 1405 za zásluhy v boji proti antikrálovi Ladislavovi Neapolskému král' Žigmund daroval hrad Nyaláb a domínium Petrovi Perényimu, čo vyvolalo viac ako storočný súdny spor medzi rodinami Dragfi a Perényi.

Od začiatku 15. storočia do poslednej tretiny 17. storočia hrad s menšími prestávkami patril do vlastníctva barónskej vetvy rodu Perényi. Napriek tomu, že jeho majitelia sa nezúčastnili na politických sprisahaniach v 16.-17. storočí a vždy ostali lojálni k panovaniu Habsburgovcov, vo Viedni bolo prijaté rozhodnutie o zničení hradu, čo sa uskutočnilo v roku 1672.

Aj ked' sú dejiny hradu Nyaláb celkom bohaté na udalosti, doposial' sa v jeho areáli a blízkom okolí vykonávali iba sporadické archeologické výskumy miestnych nadšencov (ktorí odovzdali čast' zistených starožitností do Mad’arského národného múzea v Budapešti) v rokoch 1859 a 1881 a d’alej výskumy realizované pracovníkmi Múzea prírody (Kyjiv) v 80. rokoch a Ukrajinského špeciálneho vedecko-reštaurátorského inštitútu „Ukrzachidproektrestavratcija“ (Lvov) na začiatku 90. rokov minulého storočia.

Systematický archeologický výskum hradu Nyaláb začal v roku 2007. Počas výskumnej sezóny v rokoch 2007 a 2011-2017 expedícia Užhorodskej národnej univerzity skúmala architektonické usporiadanie hradu a jeho stratigrafiu. Analýza získaného súboru nálezov svedčí o využívaní opevnenej časti od začiatku 14. storočia do polovice 17. storočia, čo väčšinou súhlasí s informáciami v písomných prameňoch (Прохненко 2014, 234-243; 2015, 117-124; 2015a, 46-47; 2016, 150-156; 2016a, 38-41; 2016b, 122-142; Прохненко-Гомоляк 2012, 170-171; 2013, 171-172; Прохненко-Жиленко-Мойжес 2013, 194-249; 2016, 123-154; Прохненко-МойжесГомоляк 2011, 213-232; Прохненко-Мойжес-Жиленко 2012, 204-248; 2013a, 142-151; 2013b, 152-163; 2014, 105-126; 2014a, 259-271; Prohnenko-Mojzsesz-Zsilenko 2012, 241-285; Prohnenko-Zsilenko 2015, 68-71; 2016, 325-379; Prohnenko-Zsilenko-Mojzsesz 2016, 273-299).

Počas prvej fázy výskumu v roku 2007 boli položené dve sondy (Прохненко-Гомоляк 2007, 83-94; Прохненко-Гомоляк-Мойжес 2007, 219-255; 2009, 296-301; 2011, 187-234; Прохненко-Жиленко 2014, 134-135; 2016а, 53-66; 2016, 131-142). Sonda 1 bola orientovaná 

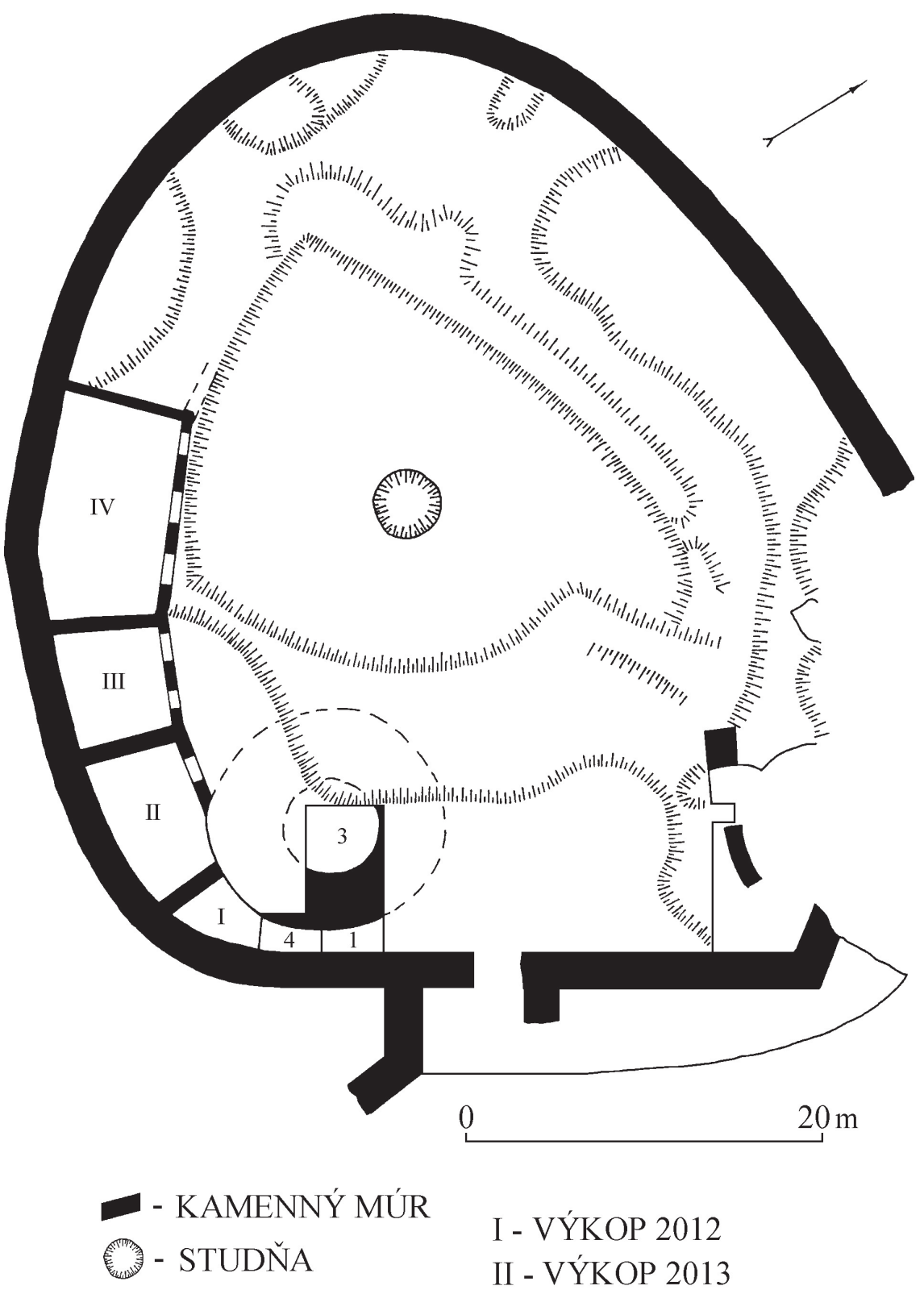

1 - SONDA 2007

I - VÝKOP 2012

II - VÝKOP 2013

3-4 - SONDY 2011

III - VÝKOP 2014

IV - VÝKOP 2015-2017

Obr. 6. Pôdorys Korolivského hradu Nyaláb.

Fig. 6. Plan of the Korolevo castle Nyaláb. 
z juhozápadu na severovýchod. Z troch strán bola ohraničená kamennými múrmi. Vrchnú vrstvu $(0-0,7 \mathrm{~m})$ predstavovala tmavosivá hlina s vel'kým počtom kostí a keramiky. V híbke 0,7 až do $1,1 \mathrm{~m}$ bola zaznamenaná vrstva čiernej humusovej pôdy, bohatej na nálezy. Táto vrstva súvisí s obliehaním hradu v druhej pol. 15. a na začiatku 16. storočia. Nižšie v hĺbke $1,8 / 2,1 \mathrm{~m}$ bola vrstva žltej hliny so stavebným odpadom. V dolnej časti vrstvy (híbka 2,05 m) boli zhluky tehál a omietky. Tu bola objavená uhorská minca Alberta (1437-1439). Nižšie pod vrstvou tehál bola vrstva vel'kých andezitových kameňov a balvanov, medzi ktorými boli zlomky interiérovej výzdoby.

Sonda 2 bola orientovaná z juhovýchodu na severozápad. Počas výskumu boli zistené tri vrstvy. Vrchná vrstva - tmavosivá humusová hlina, pod ňou hnedá hlina. Vo východnom rohu sondy bola nad podložím zistená vrstva podsýpaného štrku. Vrstva obsahovala kosti a na kruhu točenú keramiku.

Výskum v roku 2007 umožnil uvažovat' o Korolivskom hrade ako o jednom z najperspektívnejších na pokračovanie dlhodobých systematických výskumov. Následné práce vykonané počas výskumnej sezóny boli sústredené na hradnom nádvorí, kde boli skúmané tri miestnosti. Jedna z nich bola vel'ká sála (na obr. označená č. IV). Okrem nich sa preskúmala aj pomocná miestnost' (I). Mocnost' kultúrnej vrstvy bola od 4,0 do 5,0 m. Stratigrafické pozorovania umožnili rozlíšit' v skúmaných priestoroch dva hlavné horizonty (pred a po zničení hradu vojakmi rakúskej posádky v rokoch 1671-1672). Vrchný horizont tvorili masívne úlomky stien, bloky vel'kých andezitových kameňov, omietky a tehál, ktoré po výbuchu homogénne zaplnili hradné miestnosti. A spodný horizont, ktorý sa nachádzal pod úrovňou podlahy. Pozostával z hliny s vel'kým obsahom malého stavebného odpadu (omietka, kúsky tehál, kamene). Zásyp obsahoval zlomky keramiky a drobné predmety datované do 14.-15. storočia.

Analýza nálezov získaných v priebehu archeologického výskumu z Korolivského hradu (obr. 7-8) umožňuje rekonštruovat' nasledovnú situáciu. Výstavba kamenného opevnenia sa datuje do začiatku 14. storočia, ale pozorujeme slabú intenzitu využívania lokality a nevýrazný kultúrny horizont $\mathrm{z}$ tohto obdobia. Hrad bol prestavaný v 15. storočí. Po obnovení opevnenia sa formuje silná kultúrna vrstva, ktorá svedčí o intenzívnom využívaní hradu. Na začiatku 16. storočia sa z písomných prameňov dozvedáme o útoku na hrad. Otázka jeho úspechu však zostáva otvorená. Aktívny život na hrade Nyaláb pokračoval minimálne do polovice 17. storočia.

Ďalší Bronkivský hrad sa nachádza v Iršavskom okrese a bol skúmaný v roku 2008. Stojí na vrchole skalnatého kopca, ktorý miestni obyvatelia nazývajú Cárskou horou (obr. 9), pri vstupe do doliny horského masívu, ktorý obklopuje údolie rieky Bronka vhodné na osídlenie. Rieka obmýva horu z troch strán, nechávajúc úzky priechod v podobe cesty.

Hrad má približne oválny pôdorys s miernym odklonom orientovaný v smere západ-východ. Vel'kost' vyvýšenej plošiny $(35 \times 14 \mathrm{~m})$ obmedzila hradnú plochu (obr. 10). Plocha hradu v kontexte s charakteristikami umiestnenia (vynikajúcim výhl’adom z lokality) a hlavne absenciou pohodlného prístupu na hrad, umožňuje uvažovat’ o základnom funkčnom účele hradu.

Zmienky o opevnení sa v písomných prameňoch objavujú od druhej polovice 13. storočia. Král' Ladislav V. vo svojej listine z 23. mája roku 1273 vzal na dvor majstra Petra z rodu Čákovcov za účast' na dobývaní Bronkivského hradu. Listina je spojená s udalost’ami spred desiatich rokov, z obdobia vojenského konfliktu medzi Belom IV. a mladším králom Štefanom V. Jedna z potýčok sa konala pod hradbami Bronkivského hradu (Fügedi 1977, 104).

Ďalšia zmienka o Bronkivskom opevnení je datovaná do roku 1290. Král' Ondrej III. nariadil Mihályovi Ubulfy držat' obranu hradu až do jeho príchodu (CDH I, 458). Podl’a bádatel'ov takýto príkaz môže byt' spojený s preniknutím samozvanca z Pol'ska na územie Uhorska, vydávajúceho sa za princa Ondreja, brata král'a Ladislava IV., na jeseň roku 1290.

V listine z roku 1321 sa spomínajú už iba ruiny Bronkivského hradu. Nie je presne známe, aké okolnosti viedli k zániku pevnosti. Podl’a niektorých autorov spadala pod § 24 král'ovského zákona z roku 1291 o zlodejských opevneniach (Györffy 1987, 530), podl’a iných bola zničená v súlade s podmienkami mierovej zmluvy medzi Ondrejom III. a Albertom Habsburským 

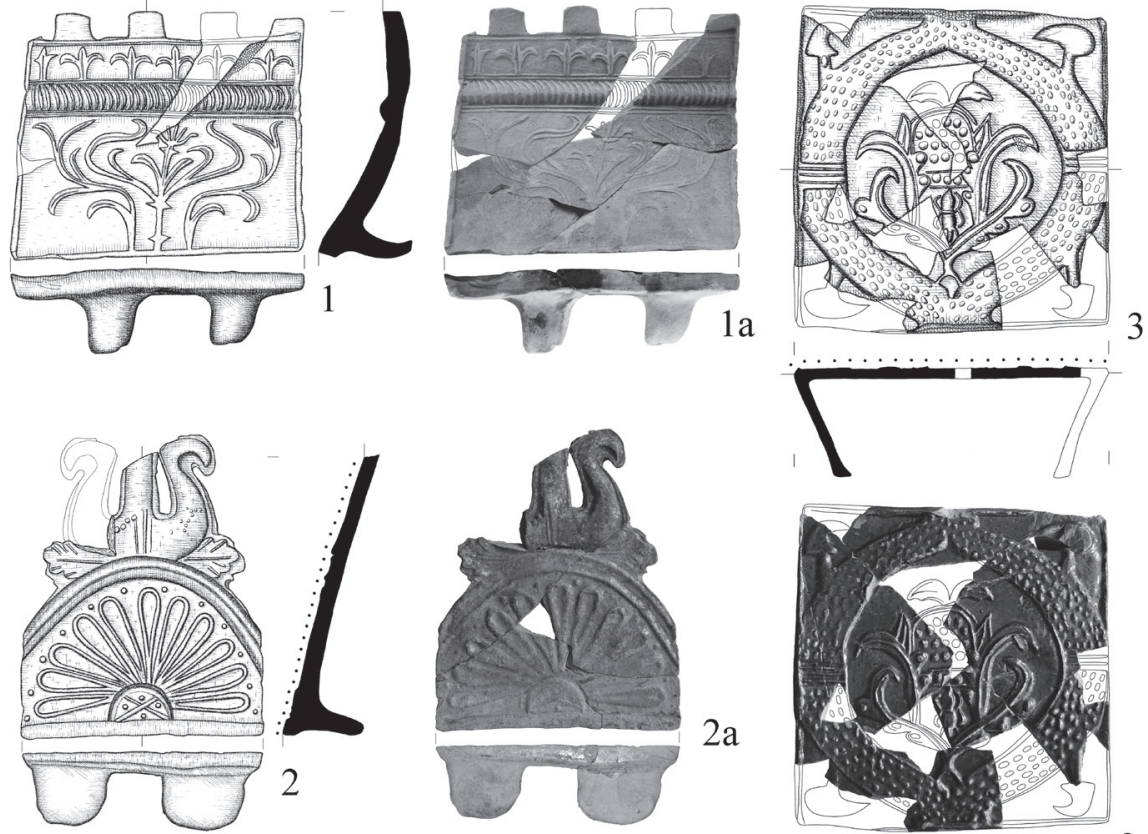

$2 a$
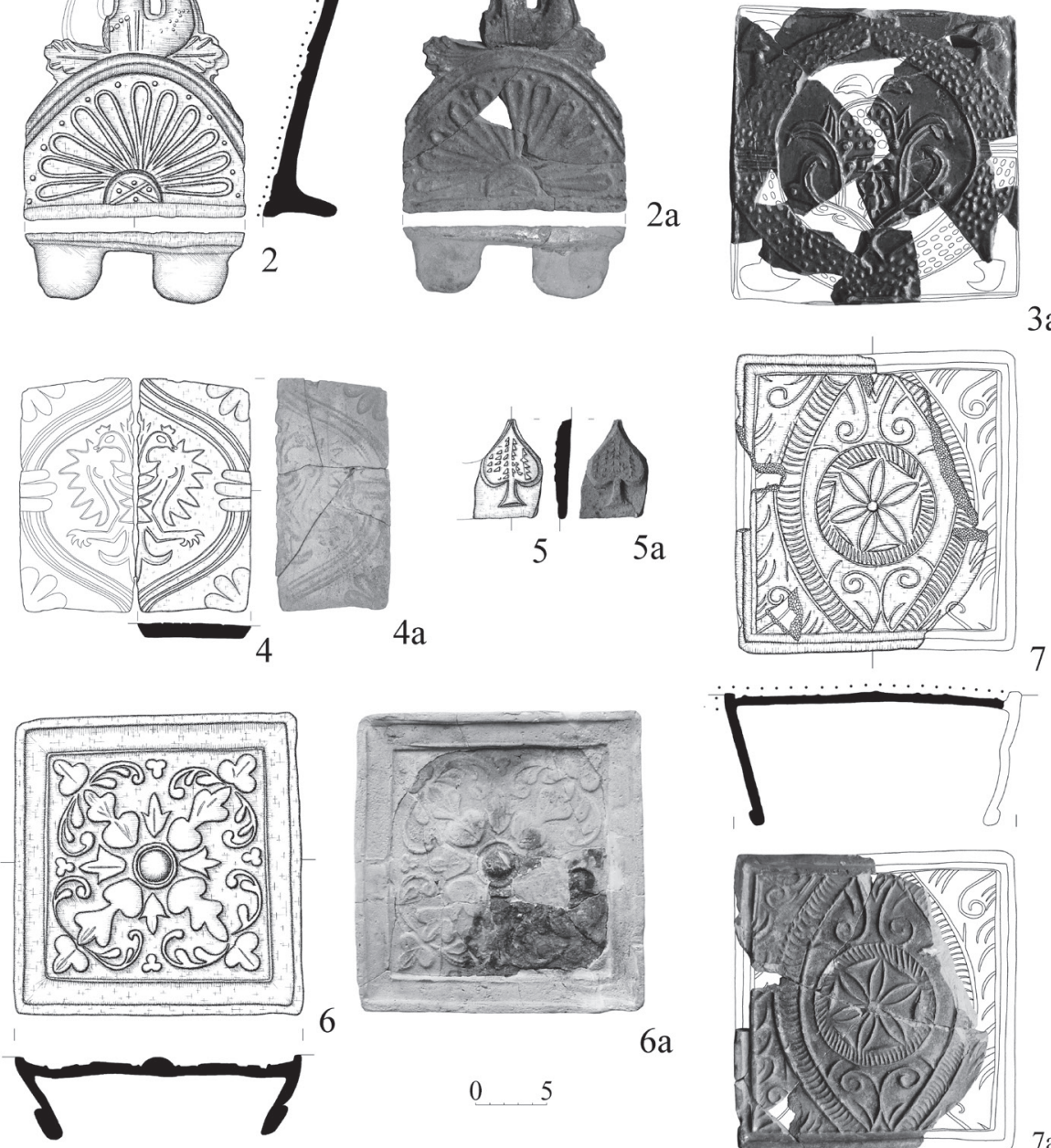

$6 a$
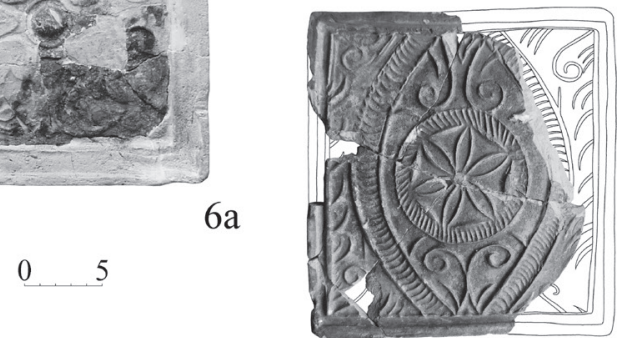

$7 a$

Obr. 7. Výber kachlíc Korolivského hradu Nyaláb.

Fig. 7. Selected tiles from the Korolevo castle Nyaláb. 

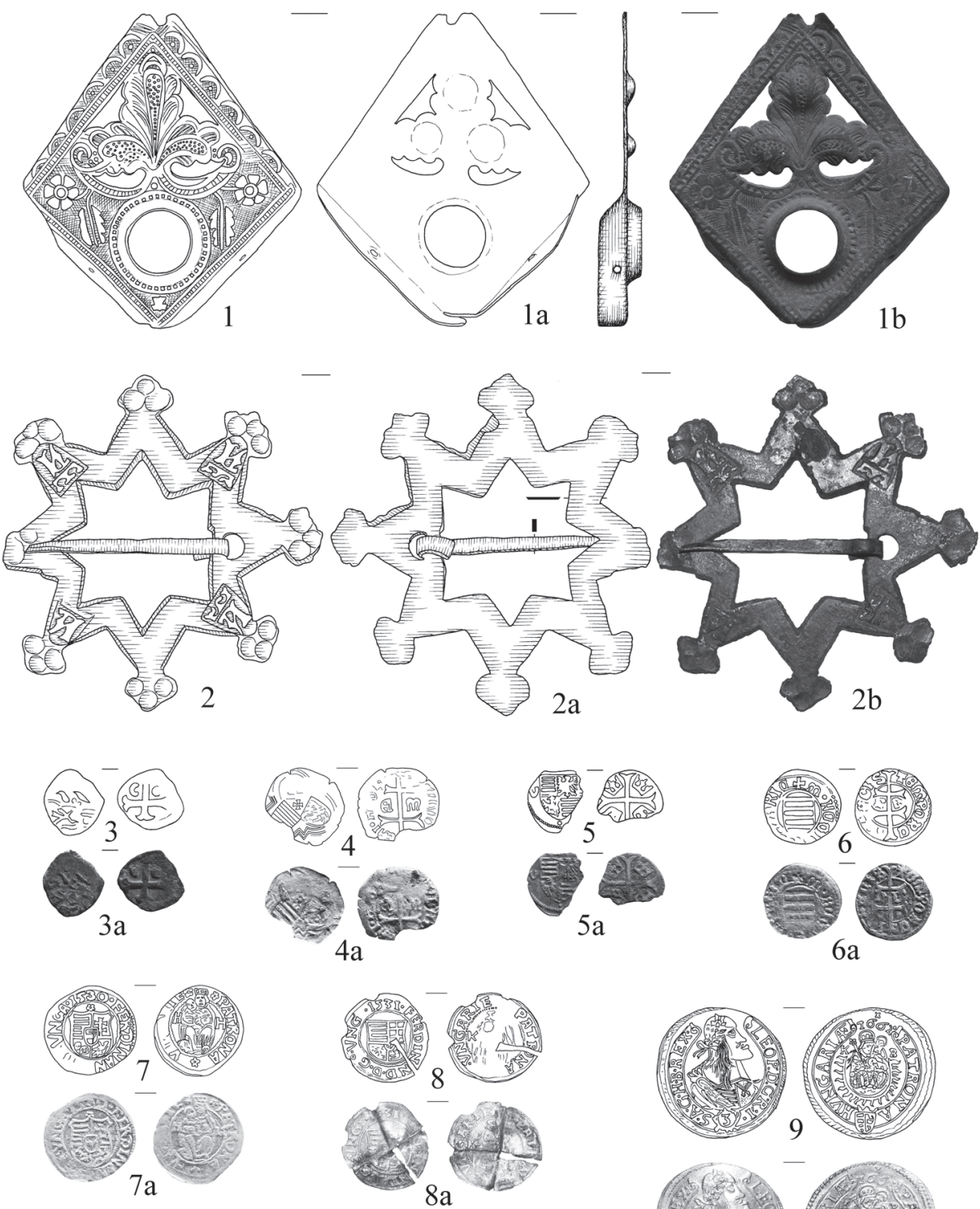

0 3

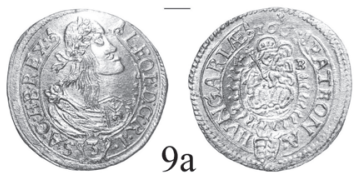

Obr. 8. Výber nálezov Korolivského hradu Nyaláb.

Fig. 8. Selected finds from the Korolevo castle Nyaláb. 


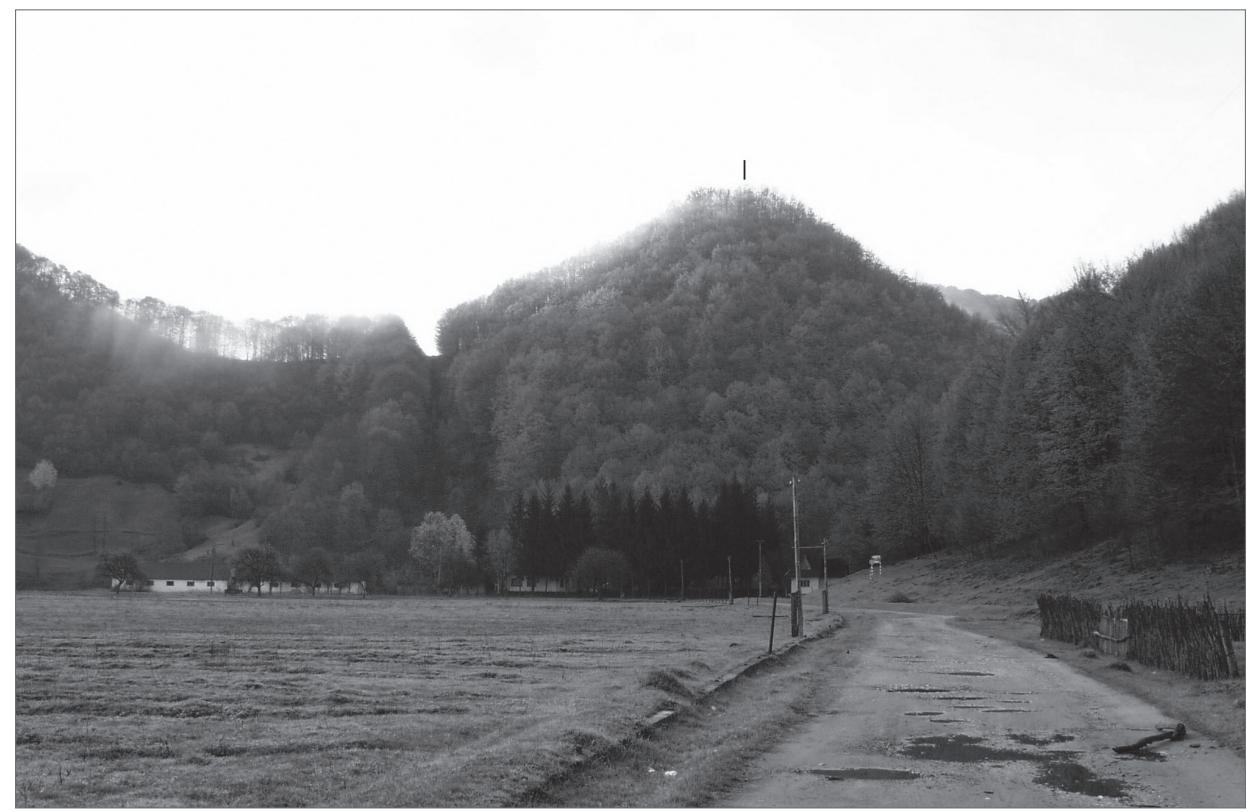

Obr. 9. Bronkivský hrad na vrchole Cárskej hory, Iršavský okres.

Fig. 9. Bronka Castle at the top of the Cárska hora mountain, Irshava district.

z roku 1291 (Kristó 1986, 152). Avšak hrad Bronka mohol byt' zničený aj počas inej epizódy občianskych vojen na prelome storočí.

Zástavba pozostáva z dvoch kamenných budov (obr. 10), ktoré sú na niektorých miestach v terénnom reliéfe sotva viditel’né. Prvou je podl’a pôdorysu valcová veža (vonkajší priemer 7,8 m, hrúbka steny - $1 \mathrm{~m}$ ), postavená vo východnej časti areálu. Tá bránila zložitý, ale najdostupnejší prístup na vrchol. Južná čast' steny hraničí vo výške $3 \mathrm{~m}$ so skalou, v ktorej je pivnica.

Druhá budova, s obdížnikovým pôdorysom, sa nachádza v západnej časti vyvýšenej roviny. Jej rozmery sú $13,6 \times 7,6 \mathrm{~m}$, hrúbka steny $-1 \mathrm{~m}$. Na úpätí severnej steny sa začína strmý svah (so sklonom $45^{\circ}$ ), medzi južnou stenou a podobným svahom - pomerne rovná trojmetrová plocha (pravdepodobne pre vchod do budovy). Západná stena hraničí s vertikálnymi skalnými výčnelkami.

Svedectvo miestneho obyvatel'stva a vizuálna prehliadka pamiatky umožňujú konštatovat', že vel'ká čast' plochy hradu bola zničená hladačmi pokladov. V dôsledku ich činnosti je na viacerých miestach premiestnená kultúrna vrstva, dokonca aj skalné podložie. Vzhl'adom na túto situáciu sme realizovali dve sondy na relatívne dobre zachovaných úsekoch pamiatky (Прохненко-Гомоляк-Мойжес 2008, 139-148; Prohnenko-Zsilenko 2016, 77-79).

Plocha sondy I $(6,0 \times 5,6 \mathrm{~m})$ je obmedzená stenami obdížnikovej stavby. Je charakterizovaná úplnou absenciou kultúrnej vrstvy (iba lístie a prepletené korene, ktoré dosahujú hĺbku od 0,1 do $0,5 \mathrm{~m}$ ) na štvorcoch siahajúcich do južnej steny, čo je spojené s činnost'ou „nelegálnych hl'adačov“. V priebehu vykopávok v severných štvorcoch pod vrchnou vrstvou bola zachytená vrstva čiernej humusovej hliny s mocnost'ou do $0,5 \mathrm{~m}$. Bližšie $\mathrm{k}$ podložiu ležala žltá hlina s prímesou vápna. Mocnost' aj tejto vrstvy bola $0,5 \mathrm{~m}$. Podložie je tvorené vyčnievajúcimi skalami, ktoré dokladujú, že hrad sa budoval unáhlene a nebolo preň pripravené miesto - základ pre fortifikačné objekty.

Medzi skalami v spodnej časti vrstvy žltej hliny boli zistené tri okrajové zlomky ručne tvarovanej keramiky, ktoré nemožno presnejšie časovo určit'. Na základe morfológie keramického cesta sa môžu datovat' od 3. až do 2. tisícročia pred naším letopočtom. 

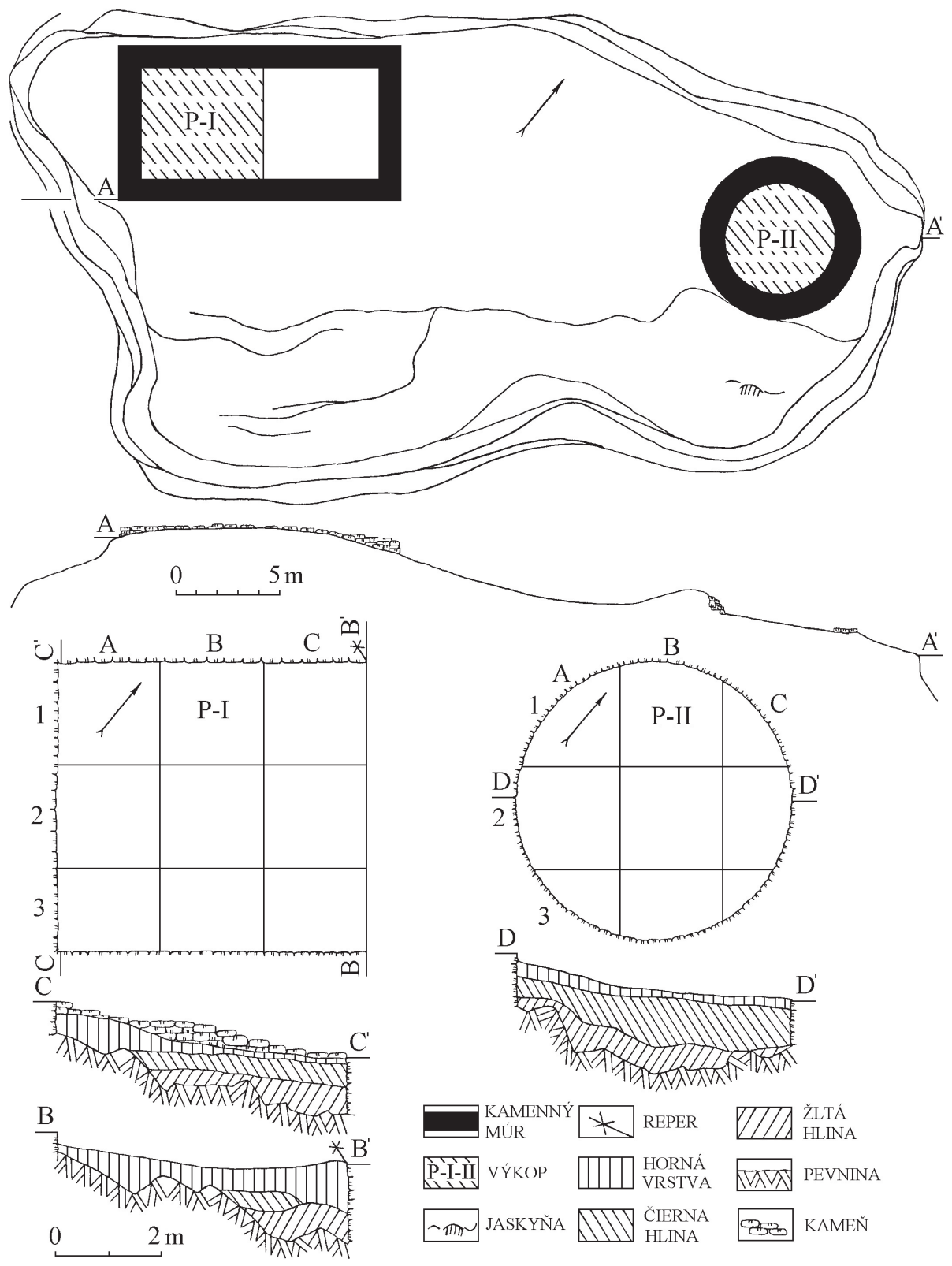

Obr. 10. Pôdorys a profil Bronkivského hradu.

Fig. 10. Plan and profile of Bronka Castle. 
V hornej časti tejto vrstvy a v zásype čiernej hliny sa našlo vel'ké množstvo archeologických nálezov: keramika, drobné predmety, kosti. Uloženie vrstiev v sonde je narušené. V dôsledku toho je materiál z rôznych chronologických horizontov zmiešaný, čo neumožňuje študovat' stratigrafiu pamiatky. V takejto situácii je možné iba vydelit’ z celého súboru podskupiny nálezov z konkrétnych časových úsekov.

Sonda II bola umiestnená vo východnej časti veže. Sekvencia uložených vrstiev bola podobná sekvencii pozorovanej v sonde I: vrchná - čierna humusová hlina (mocnost’ do $1 \mathrm{~m}$ ), spodná - žltá hlina (mocnost’ - 0,4 m), podložie - vyčnievajúce skaly. V zásype interiéru veže sa našli dva okrajové zlomky na kruhu točených hrncov.

Povaha kultúrnej vrstvy sa stala základom pre určenie východnej veže ako strážnej a obdížnikovej budovy ako obytného priestoru hradu. Analýza materiálu umožňuje určit' fázy osídlenia. Počiatočný horizont je spojený s populáciou zo záveru eneolitu a zo začiatku doby bronzovej, ktorá používala hornú čast' kopca.

Unáhlená výstavba opevnenia z pomocného stavebného materiálu sa datuje do druhej polovice 13. storočia. Zaznamenaný základný horizont osídlenia do polovice 14. storočia nie je trvalý. Medzi drobnými nálezmi dominujú nože vrátane bojových a brúsky na ich ostrenie. Drobné predmety sú zastúpené aj téglikom na tavenie farebných kovov, zlomkom ostrohy, háčikom a klincami (obr. 11).

V tej dobe sa obyvatelia hradu venovali pol'ovníctvu a rybolovu, čo potvrdzuje analýza zisteného osteologického materiálu. Vyhodnotenie zvieracích kostí svedčí o tom, že obyvatelia hradu lovili diviaky, srny, jelene a vlky. Okrem toho konzumovali bravčové a hovädzie mäso.

Menšie množstvo keramického materiálu je datované do 15. storočia Pravdepodobne hlavnou funkciou hradu počas celého tohto obdobia bolo skladovanie.

Výsledky výskumov potvrdzujú dobu výstavby hradu stanovenú v odbornej literatúre do druhej polovice 13. storočia. Získané nálezy slúžia ako základ pre charakteristiku životnej činnosti obyvatel'ov hradu, pretože d'alší archeologický výskum lokality sa zatial' neplánuje.

Na jar roku 2008 archeologická expedícia Užhorodskej národnej univerzity uskutočnila výskum hradu v obci Seredné v Užhorodskom okrese. Na rozdiel od ostatných hradov na Zakarpatskej Ukrajine je postavený na rovine v blízkosti rieky Vel’a. Do dnešného dňa sa najlepšie zachovala donjonová disp. obdobná Sárospátaku (rozmery 18,6 × 16,5 m), ktorá tvorila jadro hradu (obr. 12). Prízemie je rozdelené širokou priečkou na dve miestnosti s polosférickými stropmi, prepojené malými vstupmi. Z vonkajšej strany viedli do každej miestnosti samostatné úzke vstupy v severnej a východnej stene budovy. Pod týmito miestnost’ami sa nachádzali pivnice, do ktorých sa dalo dostat' po točitých schodiskách. Tieto schodiská sa nachádzali v severovýchodnom rohu budovy a mali starostlivo vyleštené stupne z bieleho kameňa. Nad prízemím bola priestranná sála s vysokými úzkymi oknami. Vstup do nej bol na východnej strane budovy. Budova je ukončená valbovou strechou pyramídového tvaru so zrezanými rohmi základov.

Hradné nádvorie bolo obklopené kamennými stenami. Dodatočný fortifikačný systém, podl'a pôdorysu približne štvorcovej formy, je viditel'ne zastúpený dvoma líniami valov a priekop (obr. 13). Vonkajší val ohraničuje plochu pamiatky - $200 \times 200 \mathrm{~m}$. Takmer celá jeho čast' bola výrazne zničená počas výstavby a pol'nohospodárskych prác miestneho obyvatel'stva. Výrazný dopad na hrad mala práca reštaurátorov, ktorí zničili väčšiu čast' centrálnej časti hradu a zmenili vzhl'ad valov a priekop, čo znemožňuje uvažovat' o ich skutočnej počiatočnej výške a híbke. V niektorých miestach dosahuje súčasná výška valov $3,5 \mathrm{~m}$. Podl’a svedectiev starých l’udí bol v priebehu prác zničený umelý systém cirkulácie vody (potrubie pre prítok a odtok), ktorá tiekla z rieky do priekop zo západnej strany a vytekala z nich z východnej priekopy smerom k mlynu. V súčasnosti v dôsledku akumulácie dažd’ovej vody je väčšina priekop močaristá.

Existuje množstvo legiend o Seredňanskom hrade, ktoré sa udomácnili nielen v populárnej, ale aj v odbornej literatúre. Podl'a nich je výstavba opevnenia spojená s rádom Templárov. Tento regionálny mýtus sa posilnil vzhl’adom na skutočnost', že dlhý čas sa na základe ,architektonických čŕt" výstavba hradu nesprávne datovala do 12. storočia. Pri takomto chronologickom 

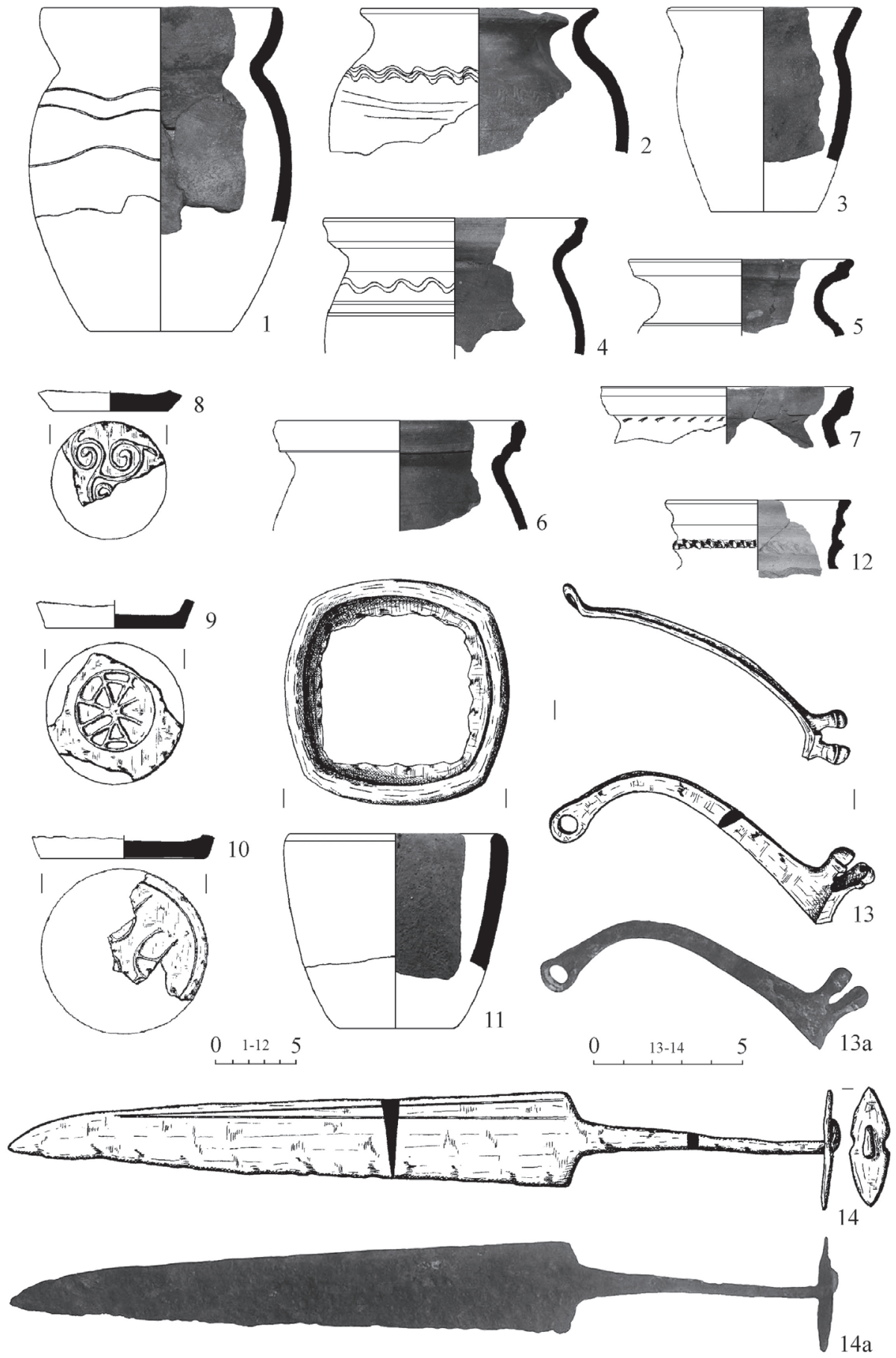

Obr. 11. Výber nálezov Bronkivského hradu.

Fig. 11. Selected finds from Bronka Castle. 


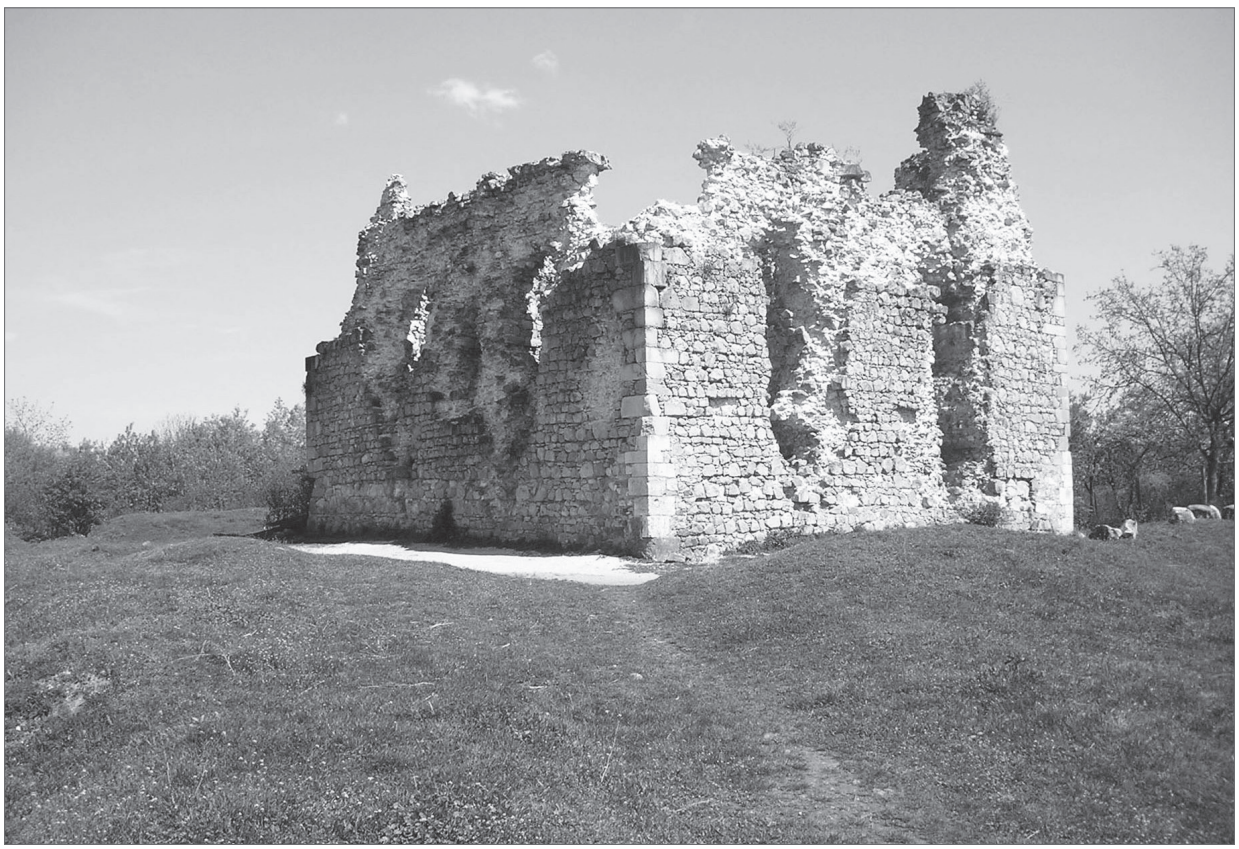

Obr. 12. Seredňanský hrad, Užhorodský okres.

Fig. 12. Seredne Castle, Uzhhorod district.

zaradení je t’ažké vysvetlit’ úlomky tehál v jadre obvodových stien centrálnej budovy, ktorých datovanie je ovel'a mladšie ako spomínané 12. storočie. Okrem toho hrady podobného pôdorysu sa na území Uhorska datujú do neskoršieho obdobia.

Navyše chceme poznamenat', že uvedený dátum výstavby hradu je v rozpore s údajmi z písomných prameňov, na základe ktorých je možné vytvorit' nasledujúcu sekvenciu udalostí spojených s výstavbou a prestavbami hradu. Obec Seredné, ktorá sa v roku 1455 spomína už ako mestečko, patrila rodu Pálóczy. Hoci rýchly vzostup rodiny začal počas panovania krála Žigmunda a na začiatku 15. storočia zástupcovia rodu obsadili vysoké štátne funkcie a za vernú službu získali významné majetky na severovýchode Uhorského král'ovstva, na svojich pozemkoch nemali žiadne hrady. V roku 1414 Pálóczyovci získali povolenie na výstavbu hradu, ale nevyužili ho, pretože v roku 1429 im darovali domínium Sárospatak s hradom Újhely (Sátoraljaújhely; Engel 1998, 55). Výstavba prvej hradnej budovy, ktorá sa neskôr stala centrom architektonického súboru, v Serednom začala až v závere 15 . storočia, kedy sa začali zakladat' vínne pivnice.

Ked' v bitke pri Moháči v roku 1526 zomrel posledný predstavitel' rodiny Antal Pálóczy, ktorý po sebe nenechal následníka mužského pohlavia, Seredňanské domínium vd’aka podpore Jána Zápol'ského do svojich rúk prebrali bratia Dobóovci.

V tejto dobe sa začína vývoj obranného systému okolo centrálnej hradnej budovy, čo potvrdzuje aj nápis pri vchode do vínnych pivníc: „Vykopané úsilím bratov Dobó: Ferenca, Ištvána a Domokoša, dedičov a majitelov Seredňanského hradu. Upevnené obrannými stenami a priekopou roku Krista 1557.“

Po smrti Ferenca Dobó mladšieho hrad najprv prešiel do vlastníctva Žofie Perényi, vnučky Domokoša Dobó, a po jej smrti následníkom Anny, sestre bratov Dobó (Takáts 1928, 416-419). Vnučkou Anny Dobó bola Zuzana Lorántffy - manželka Juraja I. Rákocziho, a takto sa Seredné ako veno dostalo do vlastníctva rodiny Rákoczi. Neskôr sa opevnenie stalo spoločným vlastníctvom rodín Forgách a Ilosvay. Podl’a urbára a jeho svedectva z roku 1689 ,pred piatimi rokmi bol 


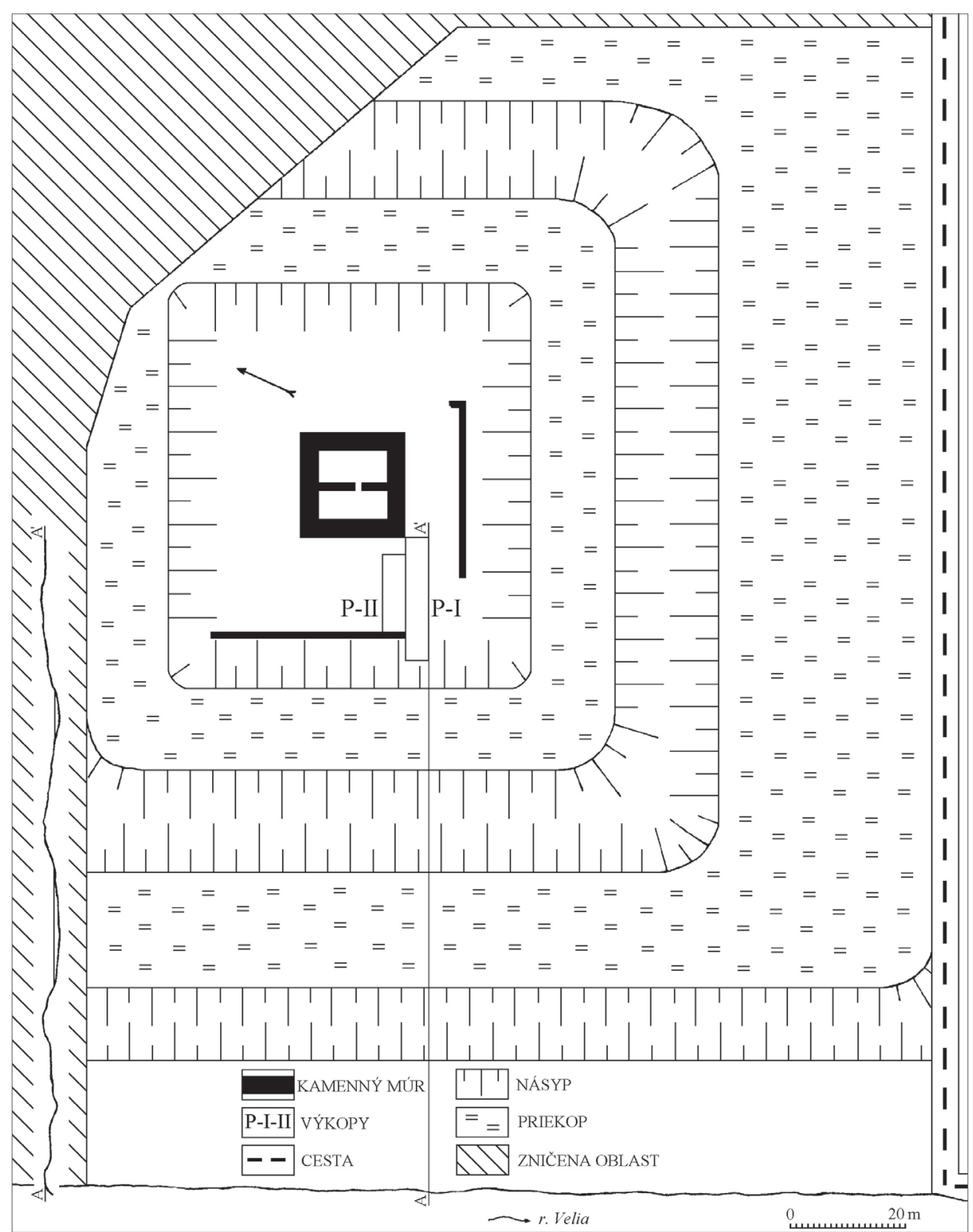

Obr. 13. Pôdorys a profil Seredňanského hradu.

Fig. 13. Plan and profile of Seredne Castle.

hrad spálený povstalcami, ale niekol'ko priestorov bolo nejako opravených a prekrytých slamou a použivajú sa dodnes“. Zánik opevnenia pokračoval aj po oslobodzovacej vojne, kedy bolo vo vlastníctve rodín Perényi a Bárkoci, ale na údržbu budovy sa prakticky nevynakladali žiadne prostriedky. V písomných prameňoch z 19. storočia sa spomínajú už iba ruiny.

V roku 2008 s ciel'om preskúmat' stratigrafickú situáciu a s ohl'adom na možnost' vykonat' archeologický výskum na ploche hradu, začala archeologická expedícia Užhorodskej národnej 
univerzity prieskum hradu na mieste hradného nádvoria (Прохненко-Гомоляк-Зомбор 2008, 189-192). Sonda I $(22 \times 4$ m) ho prerezala od južného rohu centrálnej budovy po priekopu. Mocnost' kultúrnej vrstvy, ktorá pozostávala z vrstiev hliny rôznych farieb, od sivej po čiernu (v základe), dosiahla 2,8 m. Výstavbu kamenných stien v 16. storočí stratigraficky dosvedčuje nález falošnej uhorskej mince Ferdinanda I. (1526-1564 ) z roku 1543. Pre d’alšie obdobie (17. - začiatok 18. storočia) je charakteristický kvantitatívny nárast archeologických nálezov (keramický riad, kachlice a kovové výrobky).

Pre získanie d’alších informácií archeologická expedícia Užhorodskej národnej univerzity pokračovala v prácach počas výskumnej sezóny v roku 2017 (Прохненко 2017, 131-136). Sonda II $(12 \times 4 \mathrm{~m})$. Stratigrafická situácia je v podstate totožná so stratigrafickou situáciou zaznamenanou počas predchádzajúceho výskumu. Zistené základy múrov možno priradit' k dvom rôznym chronologickým horizontom. Dve mohutné široké steny, datované do začiatku 16. storočia, boli paralelné s východnou stenou centrálnej veže a tvorili tak na okraji hradného nádvoria terasu, za ktorou sa začínala priekopa. Na konci toho istého storočia alebo na začiatku nasledujúceho (nie skôr ako v roku 1588) medzi terasou a centrálnou vežou bola postavená d’alšia mohutná stena, pri ktorej je sledované množstvo tesne umiestnených jám. Súčasne bolo dokončených niekol'ko komôr medzi starými a novými obvodovými stenami, čo viedlo k vytvoreniu nového komplexu malých miestností.

V porovnaní s terénnou sezónou v roku 2008 sa výrazne zväčšila zbierka zistených drobných predmetov (zbrane, šperky, veci pre domácnost', mince, komoditné pečate; Prohnenko-Zsilenko 2017, 56-59). Takmer všetky získané predmety sa datujú do 16. až 17. storočia (obr. 14). Do staršieho horizontu (15. storočia), ktoré s najväčšou pravdepodobnost'ou súvisí s predhradným horizontom, patria iba tri uhorské mince (Žigmund Luxemburský 1430-1437, Władysław I. 1440-1444 a Matej Korvín 1489-1490).

Keramické výrobky sú zastúpené riadom a kachlicou. Patria hlavne do 17. storočia, posledného obdobia, kedy sa opevnenie využívalo. Sortiment riadu zahŕňa rôzne formy stolovej keramiky (poháre, misky, taniere, džbány, hrnce, pokrievky), z ktorých väčšina je zdobená mal’ovanými rovnými a vlnitými čiarami červenej farby, ako aj zelenou alebo hnedou glazúrou.

Všetky kachlice, okrem niekol'kých exemplárov bez glazúry alebo polychrómnej výzdoby, sú pokryté zelenou farebnou glazúrou. Typické pre výzdobu seredňanských kachlových pecí boli rôzne kombinácie geometrických a rastlinných dekorácí́. Dodatočne s konštrukciami pecí zo 17. storočia sa používali kachlice s obrazom morských panien, ako aj exempláre, ktoré ozdobujú hornú čast' pece so ženskou tvárou a letopočtami 1637 alebo s obrazom anjela a letopočtami 1632 a 1451.

Medzi nálezmi kachlíc sa vd’aka realistickým zobrazeniam vyčleňujú dva exempláre zo 16. storočia. Na jednom z nich je zobrazený aristokrat, oblečený podl'a vtedajšej módy s prsnou ozdobou, čo potvrdzuje jeho vysoký spoločenský status (obr. 14:1). Na druhej kachlici je postava Ježiša Krista s bolestivým výrazom tváre, ktorého podporuje anjel. Podobné analógie sú známe na Korolivskom hrade Nyaláb a pamiatkach z územia Rumunska.

Výzbroj je zastúpená nábojmi do zbraní s priemerom do $1 \mathrm{~cm}$ a kanónovými gul'ami malého kalibru $(4-5 \mathrm{~cm})$.

Pre zbierku mincí je charakteristická určitá zákonitost': dominancia uhorských razieb zo 16. storočia, najmä z druhej polovice, ako aj výskyt sliezskych, pol'ských, litovských a švédskych mincí z prvej polovice 17. storočia. Boli zistené aj tri falošné razby, dve z nich pochádzajú zo 16. storočia a jedna z prvej polovice 17. storočia.

V horizonte 17. storočia bola zistená celá séria ručičiek z nástenných hodín a kovania obalov kníh. Väčšina z nich je ozdobená geometrickým dekórom, jedno lemovanie knihy je gravírované rastlinnou výzdobou po bokoch a v strede je obraz korunovaného dvojhlavého rakúskeho orla. Jedna medená spona so stopami zlátenia je ozdobená labut'ou hlavou.

Dôležitými informáciami o chronologickom vymedzení stavebných horizontov Seredňanského hradu a o určení zvláštností činnosti jeho obyvatel’ov sú nálezy kupeckých plomb 

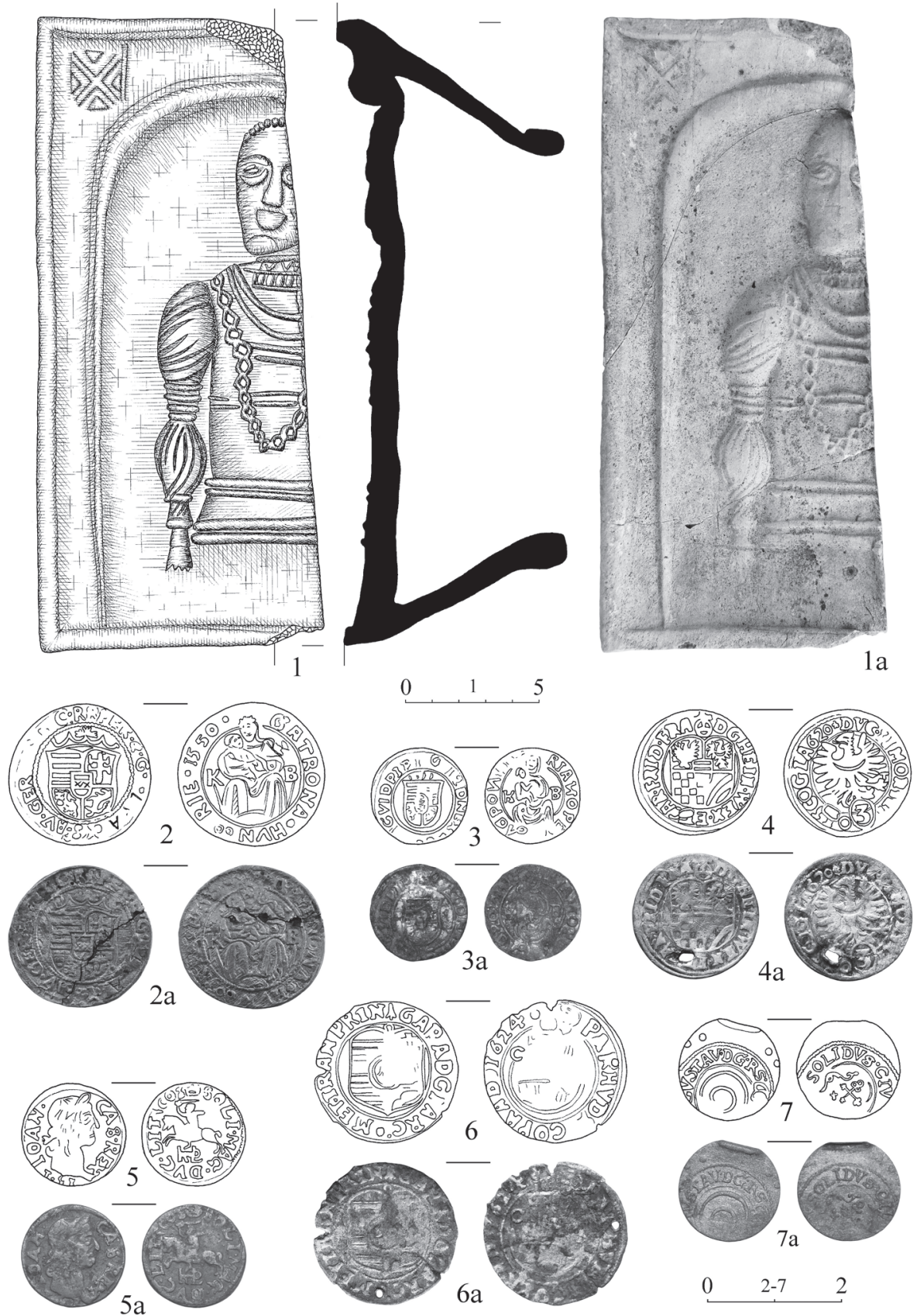

Obr. 14. Výber nálezov Seredňanského hradu.

Fig. 14. Selected finds from Seredne Castle. 
(9 exemplárov), ktoré v takejto koncentrácii na území Zakarpatia boli zistené po prvýkrát. Seredňanské exempláre slúžia ako jasné ukazovatele oblastí regionálneho obchodu na konci 16. a na začiatku 17. storočia.

Sú to dve vel'ké plomby z Wschovy (bývalý Fraustadt), jedna je z Gdanska, ako aj malé plomby s takzvaným gmerkom (rodinným znakom), ktorých pôvod je s najväčšou pravdepodobnostou spojený s územím Pol'ska. Ich analýza v kombinácii s nálezmi iných pamiatok z mikroregiónu umožňuje hovorit' o dobových obchodných aktivitách na uvedenom severnom (pol'skom) území (Прохненко-Мордовін 2017, 89-101).

Celý súbor archeologických nálezov získaných počas výskumov Seredňanského hradu v roku 2017 sa chronologicky zhoduje s dátami zaznamenanými v písomných prameňoch. V komplexe umožňujú určit' výstavbu objektu pri rieke Vel'a do 15.-16. storočia. Do polovice 16. storočia sa objekt stal jadrom hradného komplexu, ktorého fungovanie je doložené až do začiatku 18. storočia.

V roku 2009 v súlade s plánom prác sa výskum realizoval na Sileckom a Kvasivskom hrade. Tu boli preskúmané menšie úseky, z ktorých sa nálezy stali základom pre určenie doby ich existencie.

O Sileckom hrade sa v písomných prameňoch nezachovala žiadna zmienka. Pravdepodobne ho postavili miestni feudáli, zástupcovia rodu Ilosvay. Ruiny opevnenia boli rozobrané v 19. storočí kvôli výstavbe nového kostola v Iršave (Lehoczky 1996, 529-532).

Pozostatky opevnení sa nachádzajú na severnom okraji obce Silce (Iršavský okres), na vrchole hory Boduliv (obr. 15). Úpätia hory boli zo severnej a severozápadnej strany podmáčané. Z juhovýchodu vo vzdialenosti 200 metrov od úpätia tečie rieka Iršavka, ktorá preteká v blízkosti rieky Boržava. Východné a severozápadné svahy hory sú strmé, juhozápadné sú mierne naklonené.

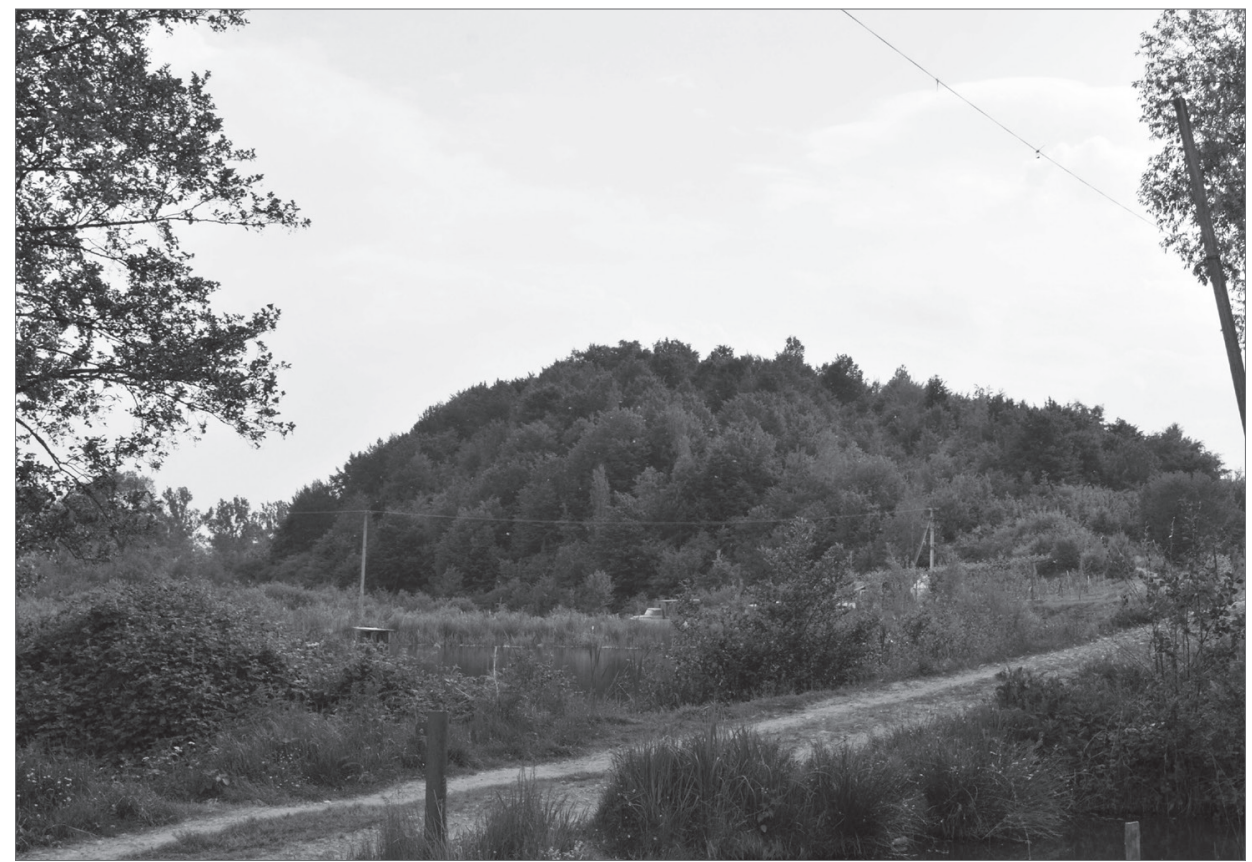

Obr. 15. Silecký hrad na vrchole hory Boduliv, Iršavský okres.

Fig. 15. Silce Castle at the top of the Boduliv, mountain Irshava district. 


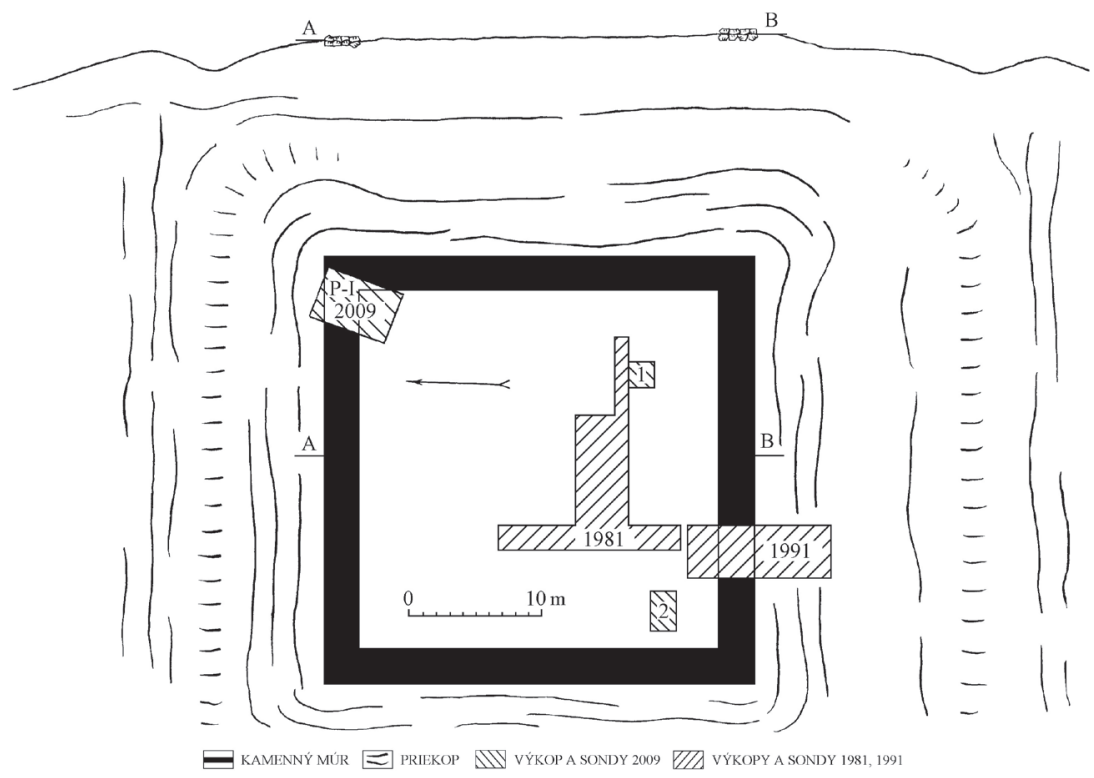

Obr. 16. Pôdorys a profil Sileckého hradu.

Fig. 16. Plan and profile of Silce Castle.

Pôdorys hradu sa určoval podl’a zvyškov jeho kamenných základov. V pôdoryse má štvorcovú konfiguráciu s vel'kostou $32 \times 32 \mathrm{~m}$. Zo severnej a južnej strany je hrad dodatočne chránený priekopami a násypmi položenými pozdíž múrov (obr. 16).

Po prvýkrát pamiatku skúmala archeologická expedícia v roku 1981 pod vedením S. I. Peňaka. Na základe zhromaždeného keramického materiálu výskumník stanovil tri kultúrno-chronologické horizonty (3.-2. storočie pred n. 1., 10.-11. storočie a 13.-14. storočie). V roku 1991 výskum na lokalite Boduliv obnovil O. V. Dzembas. Ten zistil malé množstvo fragmentárnej keramiky, ktorá je datovaná do doby halštatskej a do obdobia stredoveku (10.-11. storočie).

Kvôli malému množstvu nálezov získaných počas výskumu Boduliva, bolo nevyhnutné opät' venovat' pozornost' tejto lokalite. S ciel'om získat' dodatočné údaje boli realizované dve sondy v oblasti priekopy, ohraničenej kamenným základom (Прохненко-Гомоляк-Зомбор 2010, 346-348; obr. 16).

Sonda I s rozmermi $4 \times 6 \mathrm{~m}$ sa pripájala k severozápadnému rohu zničenej budovy. Vrchná vrstva $(0,4 \mathrm{~m})$ pozostáva z vrstvy kameňov, ktorá vznikla pri rozoberaní stien miestnymi obyvatel'mi. Pod ním až k podložiu ležala kultúrna vrstva s mocnost'ou do $0,8 \mathrm{~m}$. Bola vyplnená malým množstvom ručne tvarovanej halštatskej a na kruhu točenej stredovekej keramiky.

Podobná situácia bola zistená so sondami. Jediným objektom bolo ohnisko, ktoré sa nachádzalo $\mathrm{v}$ sonde 1 . V pôdoryse malo kruhový pôdorys s priemerom $1 \mathrm{~m}$ a híbkou $0,2 \mathrm{~m}$. Bolo zaplnené uhlím a zvieracími kost’ami. Pri ohnisku sa nachádzali zlomky stredovekých hrncov. Okrem zlomkov riadu v sonde 2 pod vrstvou kameňov bola zistená čast' fajky datovaná do 18. storočia. Tento nález, charakter vrstvy, ako aj názov hôr „kameňolom“ u miestneho obyvatel'stva naznačujú, že steny hradu rozoberali na stavebný materiál v novoveku.

Keramický materiál, získaný počas výskumov (obr. 17), umožňuje datovat' výstavbu hradu do druhej polovice 13. storočia. 

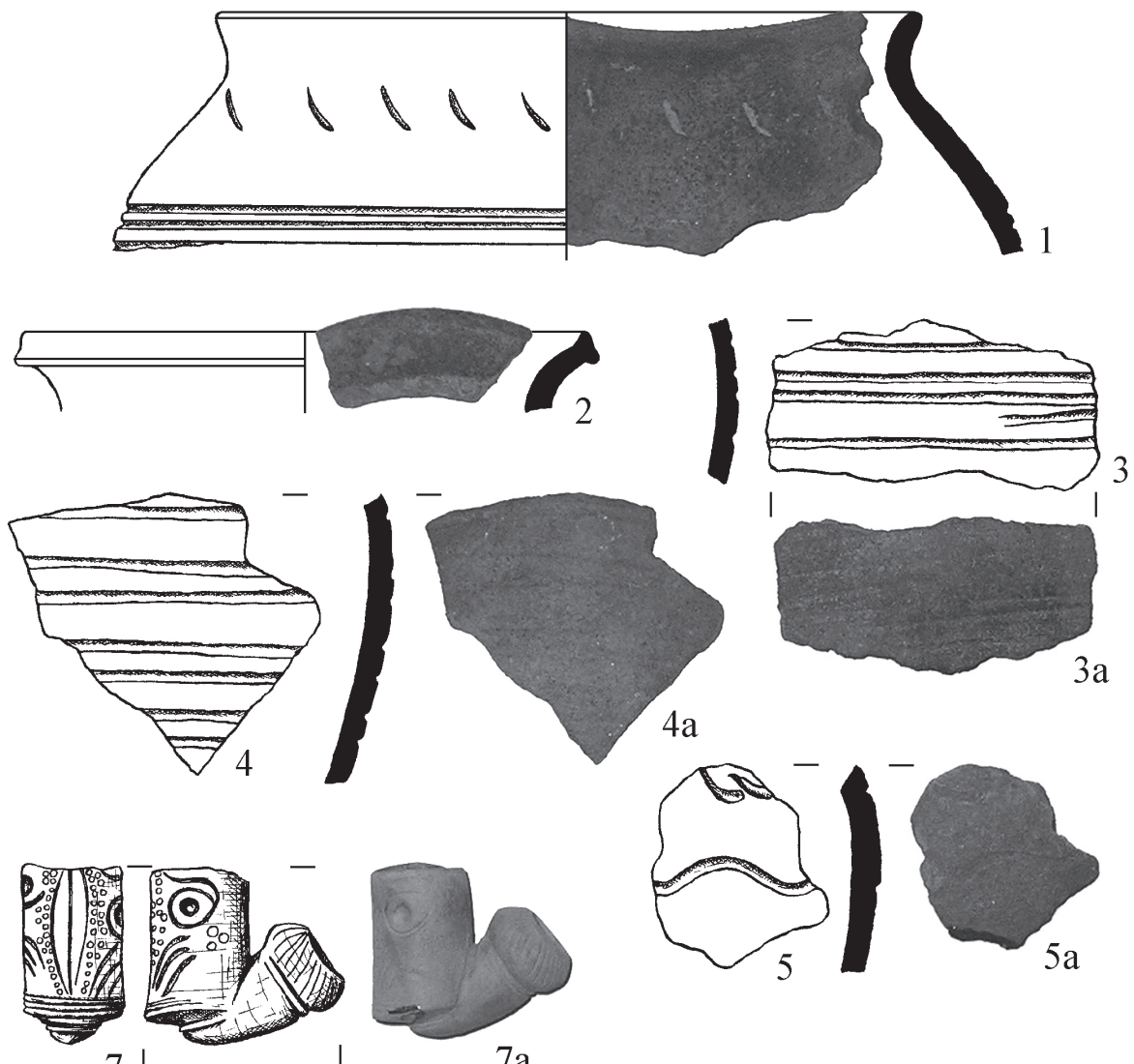

71

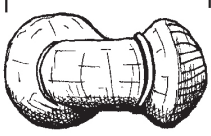

$7 \mathrm{a}$
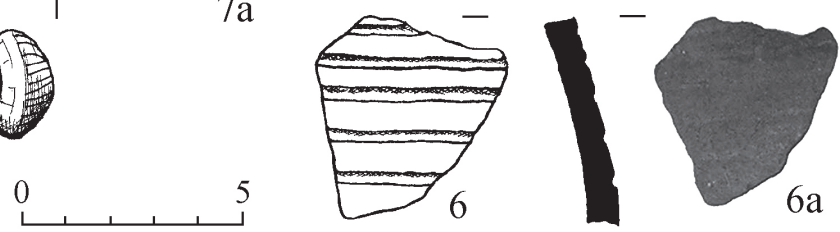

Obr. 17. Keramické nálezy Sileckého hradu.

Fig. 17. Pottery finds from Silce Castle.

Druhý z hradov, skúmaných v roku 2009, sa nachádza na východnom okraji obce Kvasovo v Berehivskom okrese. Je postavený na vrchole skalnatého kopca. Jeho severné a severovýchodné svahy, ktoré sa tiahnu od rieky Boržava, sú strmé, južné a juhozápadné sú mierne naklonené.

Čast' fortifikačného komplexu bola zničená v dôsledku hospodárskej činnosti v 20. storočí. V súčasnosti sa z hradu zachovali základy a čast' stien z vel'kých andezitových blokov (obr. 18). Ich hrúbka je do $2 \mathrm{~m}$.

V pôdoryse mal hrad tvar trojuholníka s okrúhlou vežou v južnom rohu. Plocha centrálnej časti je $450 \mathrm{~m}^{2}$. Vnútorný priemer veže je $9 \mathrm{~m}$. K nej prilieha priekopa asi $4 \mathrm{~m}$ hlboká, vykopaná pozdíž západnej steny hradu (obr. 19). 


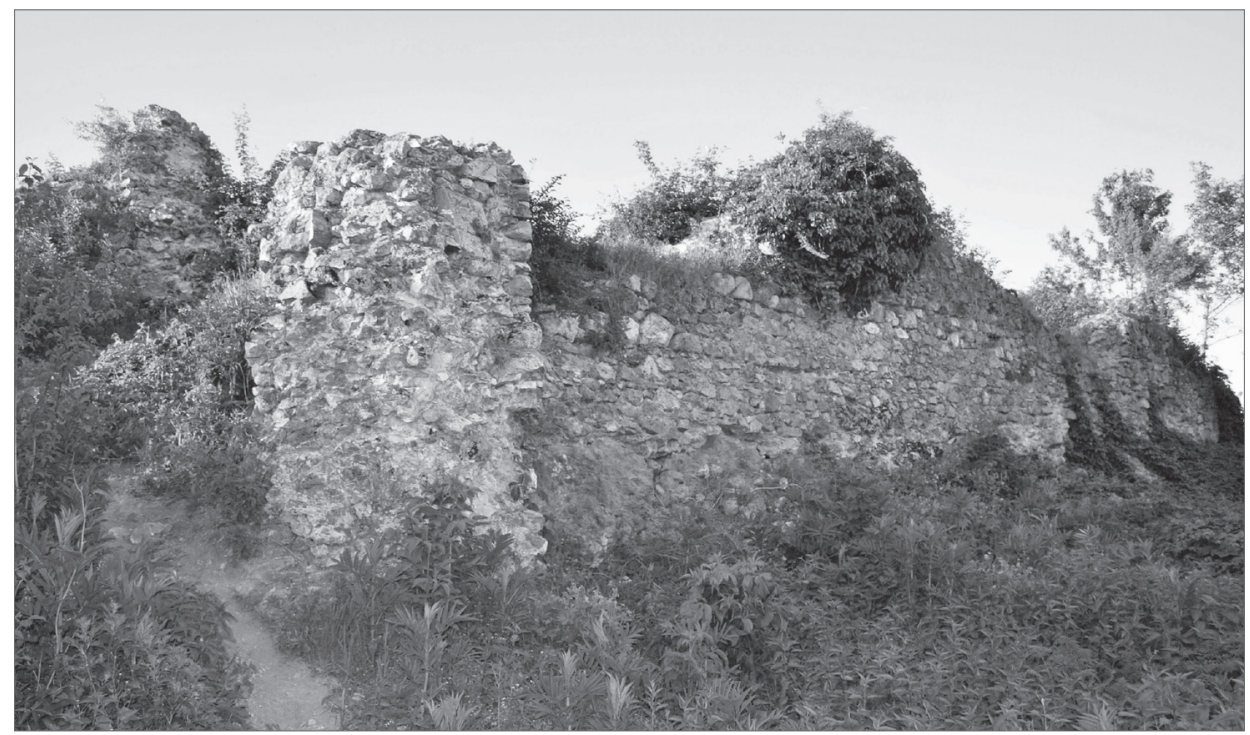

Obr. 18. Kvasivský hrad, Beherivský okres.

Fig. 18. Kvasovo Castle, Beheriv district.

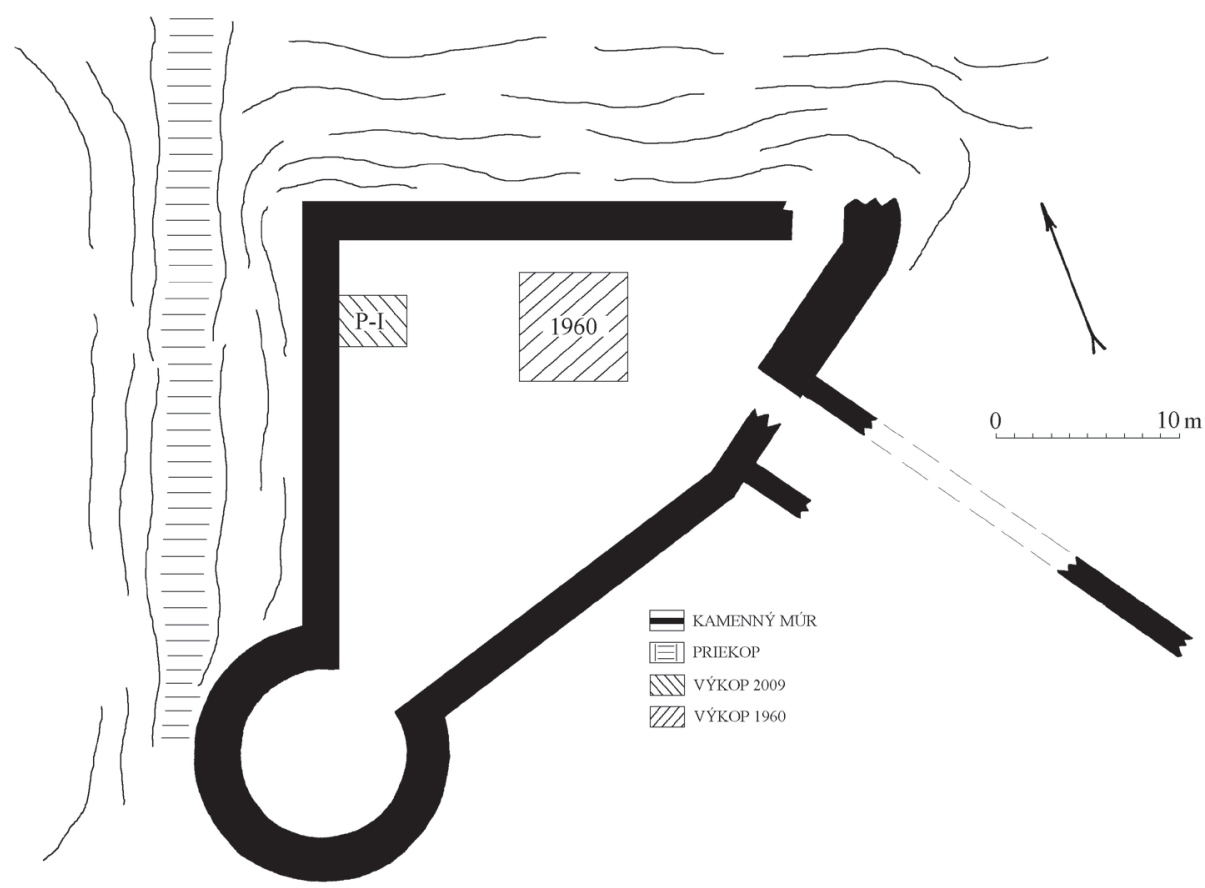

Obr. 19. Pôdorys Kvasivského hradu.

Fig. 19. Plan of Kvasovo Castle. 
Prvá zmienka o obci Kvasovo je v písomných správach z 8. mája 1390, kedy ho král’ Žigmund spolu s Varijovym daroval dvornému rytierovi královnej Márie, magistrovi Jánovi, synovi Juraja z Michaloviec (de Nagymihályi; ZsO I, 1487). Na začiatku 15. storočia obec prešla rodu Jakci a neskôr do vetvy rodu Bátori-Szaniszlófy. Koncom storočia zástupcovia rodu Mathuznai čiastočne ako veno, čiastočne ako kúpený majetok získali Kvasivský hrad spolu s domíniom (Lehoczky 1996, 548-549). V roku 1540 Juraj a Pavol Mathuznai predali hrad chustskému kastelánovi Krištofovi Kávássymu. Vrátit’ majetok rodu sa podarilo až v roku 1546. Koncom roku 1550 - na začiatku 60. rokov 16. storočia v období zintenzívnenia vojny medzi králom Ferdinandom a Jánom Zápol’ským Pavol Mathuznai, využívajúc politickú nestabilitu, zmenil Kvasivskú pevnost' na sídlo lúpežníkov, ktorých sa obávalo celé okolie.

Situácia sa natol'ko vyhrotila, že na zákonodarnom zhromaždení v roku 1563 v Prešporku vrchný velitel' dostal príkaz na prešetrenie vhodnosti d’alšej údržby Kvasivského hradu. Ak by sa preukázal význam hradu v obrannom systéme král'ovstva, vrchný velitel' mal za povinnost' zaviest' poriadok do posádky a zastavit' lúpeže. $\mathrm{V}$ opačnom prípade mal byt' hrad zničený.

Pretože v tom čase región podliehal Jánovi Zápol'skému, rozhodnutie zostalo iba na papieri. Iba o rok neskôr v roku 1564 sa král'ovskému vojsku pod vedením Lazara Schwendiho podarilo obsadit' región a zmocnit' sa okolitých pevností vrátane Kvasova. V tom istom roku bol hrad zničený (Budai 1814, 177).

Z týchto písomných prameňov vyplýva, že hrad vznikol koncom 15. storočia, ale v odbornej literatúre bez odkazu na konkrétne dokumenty sa uvádza skorší dátum - 14. storočie. Pre stanovenie stratigrafie hradu počas terénnej sezóny v roku 2009 expedícia Užhorodskej národnej univerzity vykonala terénny výskum (Прохненко-Гомоляк-Зомбор 2010, 346-348).

Sonda I s rozmermi $3 \times 4 \mathrm{~m}$ bola situovaná pri západnej stene. Kultúrna vrstva na tomto úseku mala mocnost' až do 3,2 m. Jej vrchný horizont $(1 \mathrm{~m})$ sa skladal zo stavebného odpadu (kamene, tehly, omietka). Nižšie boli položené vrstvy tmavosivej a svetlohnedej hliny. Podložie skalnatá hornina, je pokryté vrstvou kameňov s vel'kost'ou $0,2-0,3 \mathrm{~m}$.

V centrálnej časti výkopu pod násypmi stavebného odpadu z híbky $1 \mathrm{~m}$ boli vysledované obrysy jamy s priemerom $1 \mathrm{~m}$ a híbkou 1,25 m. Pri dne jamy bol zistený otvor do hradnej steny. Výplň jamy pozostávala z tmavej hliny s vel'kým obsahom keramiky a zvieracích kostí. Osteologické pozostatky predstavujú kosti hovädzieho dobytka, ošípaných, vtákov a rýb.

Hlavným hmotným materiálom, získaným počas výskumu hradu, boli na kruhu točené hrnce. Podl'a analógií z iných častí Horného Potisia sa tento riad datuje do 16. storočia, čo bolo na tomto výskume potvrdené dvomi uhorskými mincami Ferdinanda I. (1526-1564), razenými $\mathrm{v}$ rokoch 1553 a 1555.

Okrem keramiky boli počas výskumu hradu získané aj kovové predmety. Sú to železné klince, kušová skrutka, mušketové gul'ky a bronzové ozdobné dosky (obr. 20).

Stratigrafia Kvasivského hradu umožňuje hovorit' o dvoch etapách osídlenia územia. Prví obyvatelia sem prišli v 2. tisícročí pred n. 1. a koncom 15. storočia tu vznikla pevnost'.

Počas výskumnej sezóny v roku 2009 bol preskúmaný aj kaštiel’ v obci Činadievo v Mukačevskom okrese. Lokalita sa nachádza na rovine, vo vzdialenosti 200 metrov od rieky Latorica, na jej pravom brehu. Centrálnou čast’ou architektonického súboru je dvojposchodová budova, v pôdoryse neúplný obdížnik s dvomi rohovými trojpodlažnými vežami (obr. 21-22). Hrúbka stien budovy presahuje $1 \mathrm{~m}$. Priekopa okolo kaštiel'a sa nezachovala. O jej existencii svedčia iba príbehy starých l'udí.

Obec Szentmiklós (neskôr Beregszentmiklós, bývalý názov Činadieva) sa spomína od 12. storočia. Koncom 14. storočia mestečko patrilo rodine Pérenyi. V roku 1403 Peter Perényi získal povolenie na výstavbu opevneného paláca, ale pravdepodobne ho nepoužil (Lehoczky 1996, 660).

V priebehu 16.-17. storočia Činadievskym domíniám za rôznych podmienok vládli zástupcovia rodov Telegdi, Nyári, Lónyay, Eszterházy. Práve Michal Telegdi získal v roku 1583 povolenie od král’a Rudolfa na výstavbu kaštiel’a, ktorú ukončovali až jeho synovia Ján a Pavol (Emődi 2005). 

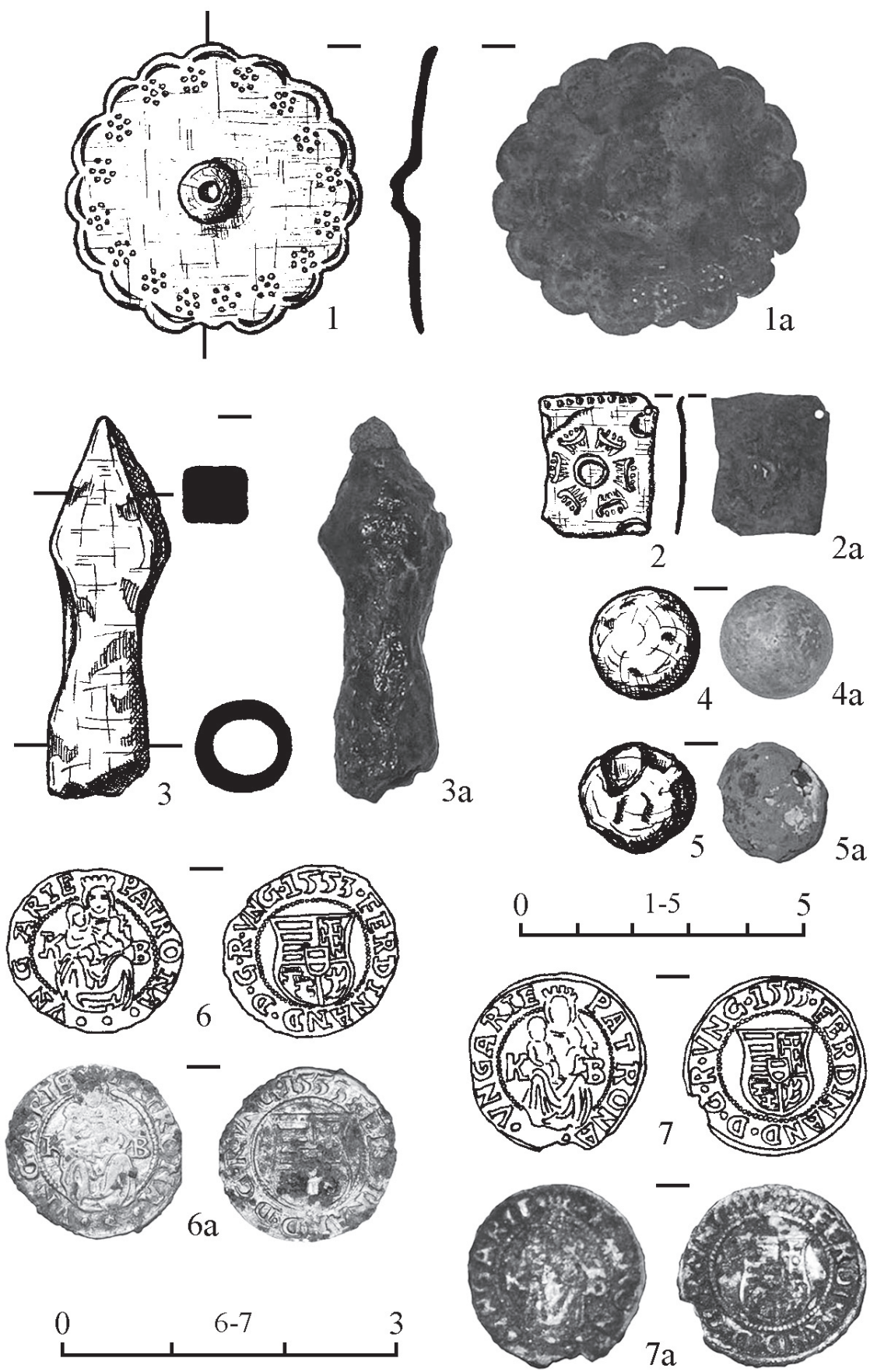

Obr. 20. Výber nálezov Kvasivského hradu.

Fig. 20. Selected finds from Kvasovo Castle. 


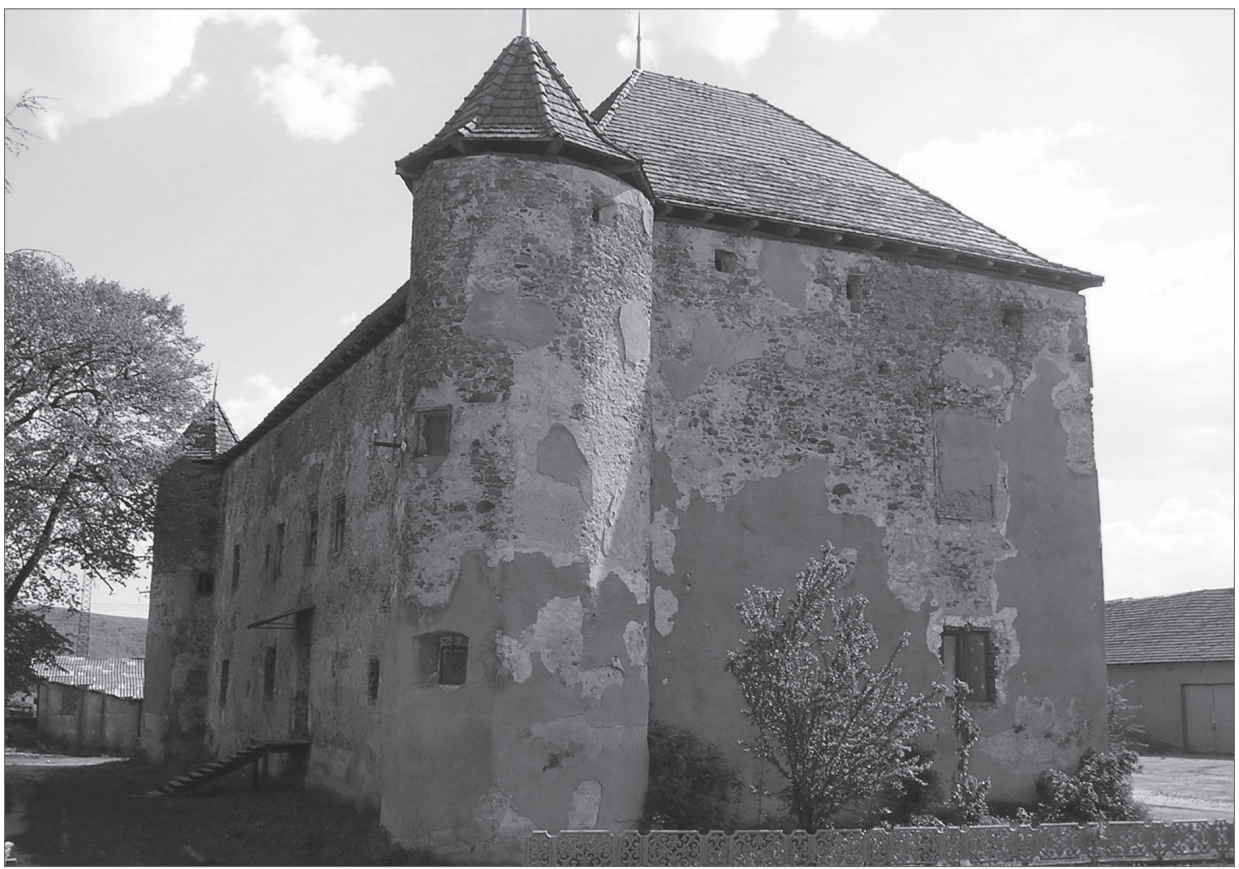

Obr. 21. Činadievsky kaštiel', Mukačivský okres.

Fig. 21. Činadieve Castle, Mukachevo district.

V roku 1669 so súhlasom krála Leopolda rodina Rákoczi odkúpila Činadievo od vdovy Juraja II. Drugeta Márie Eszterházyovej za 65000 toliarov. Po smrti Františka I. Rákócziho domínium zdedila Žofia Bátori, ktorá ho neskôr odovzdala Ilone Zríni a jej detom. Počas povstania v rokoch 1703-1711 tu často býval František II. Rákoczi.

Po uzavretí Satmárskej mierovej zmluvy sa celý Rákocziho majetok vrátane Činadievskeho domínia stal majetkom krála a v roku 1726 ho získal gróf Lothar Franz Schönborn (Lehoczky 1996, 662).

Aby expedícia Užhorodskej národnej univerzity zistila stratigrafiu, v blízkosti východnej steny paláca bola realizovaná sonda (rozmery $2 \times 4 \mathrm{~m}$ ). Podla výsledkov stratigrafických pozorovaní a zberu hmotného materiálu sa rozlišujú dva hlavné horizonty osídlenia tohto priestoru.

Horizont I $(0-0,4 \mathrm{~m})$ reprezentujú hlinené výrobky. Sortiment keramiky zahŕňal zlomky na kruhu točených hrncov zo 16.-17. storočia, úlomky kachlíc a drobné nálezy: zlomok fajky, železný klinec a mincu Mateja Korvína z rokov 1489-1490 (obr. 23:1-3, 5-6, 10-11).

Horizont II $(0,4-0,8 \mathrm{~m})$. Sem patria štyri zlomky na kruhu točených hrncov hnedej farby z konca 13.-14. storočia súvisiace s osídlením pred výstavbou kamenných stavieb (obr. 23:4, 7-9).

\section{Záver}

Archeologické práce expedície Užhorodskej národnej univerzity na hradoch v Zakarpatskej oblasti na Ukrajine umožňujú spresnit' a v niektorých prípadoch aj dementovat' tvrdenia zaužívané v odbornej literatúre. Na konkrétnom hmotnom materiáli sa ponúka nová chronologická schéma historického vývoja stredovekých pamiatok (Prohnenko-Mojzsesz-Zsilenko 2013, 203-250).

Pre všetky skúmané body sú charakteristické staršie sídliskové horizonty, ktoré svedčia o tom, že vol'ba práve týchto miest na osídlenie nebola náhodnou. Vo Vynohradove bola 

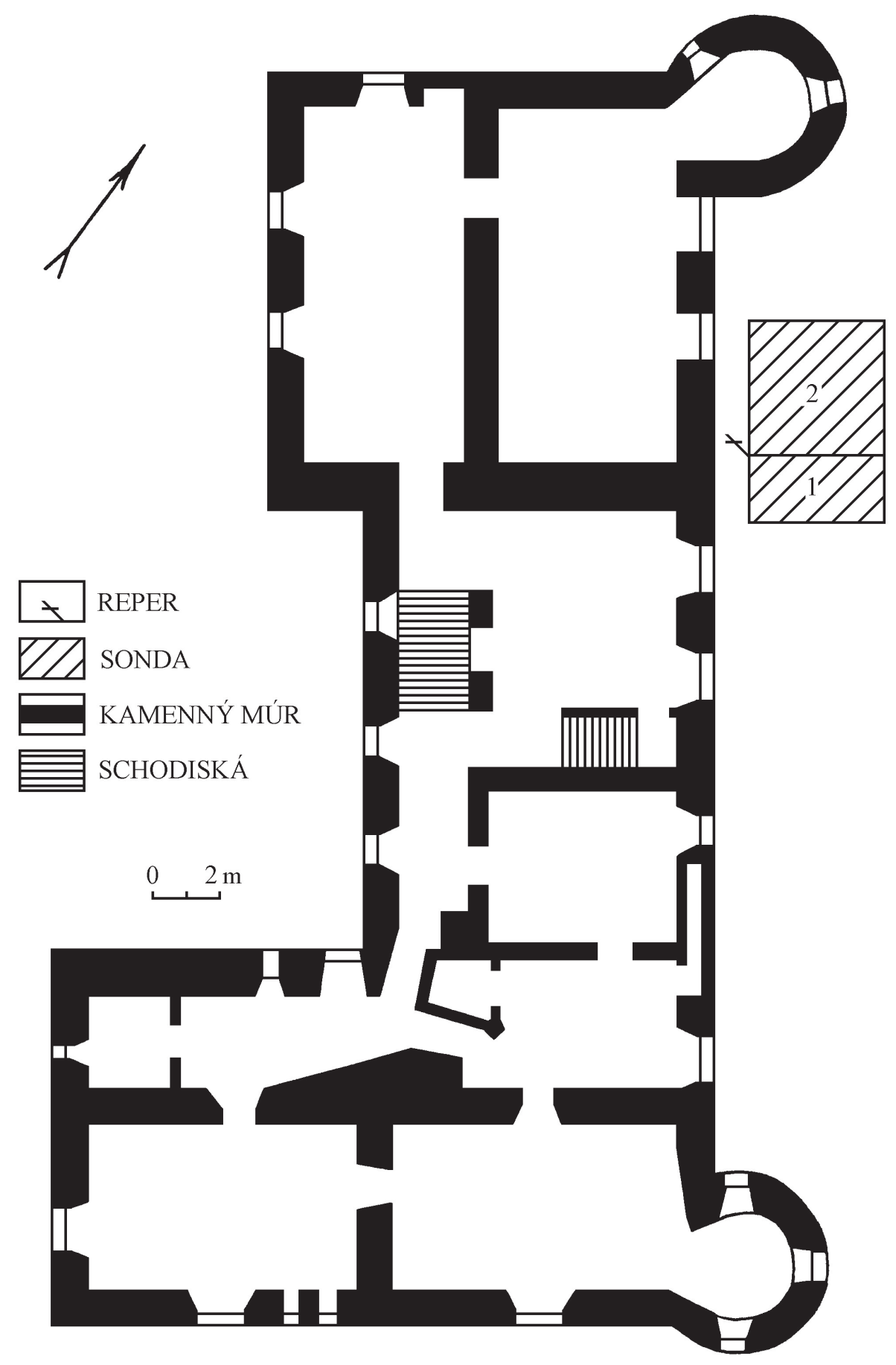

Obr. 22. Pôdorys Činadievskeho kaštiel’a.

Fig. 22. Plan of Činadieve Castle. 

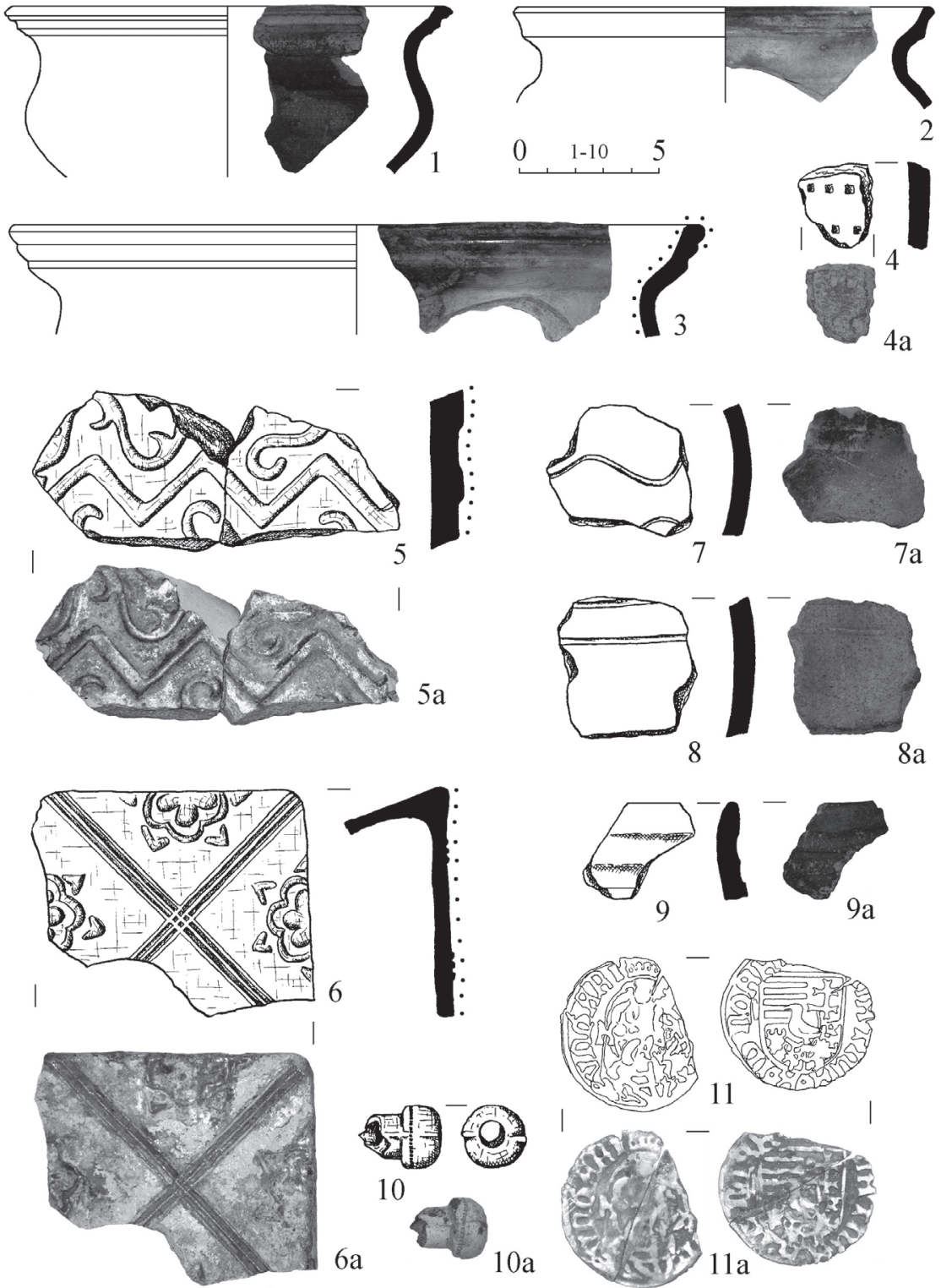

$\begin{array}{lll}0 & 11 & 1\end{array}$

Obr. 23. Výber nálezov Činadievskeho kaštiel'a.

Fig. 23. Selected firnds from Činadieve Castle. 
zaznamenaná silná vrstva z neskorej doby bronzovej (kultúra Suciu de sus 14.-12. storočia pred n. 1.) a v obciach Seredné, Korolevo, Bronka sa našlo malé množstvo nálezov z 3.-2. tisícročia pred n. 1., ktoré nemožno presnejšie určit'. Nedoložené sú tvrdenia na Vynohradivskom a Korolivskom hrade o existencii horizontu z 10.-11. storočia n. 1. V Serednom neboli zistené horizonty z 12.-14. storočia, ktoré sú uvádzané v odbornej literatúre.

Najstaršie nálezy (koniec 13. storočia), súvisiace s výstavbou kamenných opevnení, boli zaznamenané v obciach Bronka a Silce. V súčasnosti sa začiatok výstavby Vynohradivského a Korolivského hradu datuje do začiatku 14. storočia, pri tom je však potrebné zdôraznit', že na obidvoch hradoch je kultúrny horizont 14. storočia zastupený len malým množstvom keramiky. Hradné prestavby sa uskutočňovali v Koroleve v 15. storočí a vo Vynohradove na začiatku 16. storočia. Po obnovení opevnenia v Koroleve sa formuje silná kultúrna vrstva, ktorá dokladá intenzívnu činnost'. Na Vynohradivskom hrade stredovekú kultúrnu vrstvu reprezentuje menší počet fragmentárneho materiálu, čo tu môže vysvetlit' krátke obdobie fungovania františkánskeho kláštora. Do rovnakého obdobia (koniec 15. - začiatok 16. storočia) datujeme vznik hradu v Serednom. Tiež je potrebné poznamenat', že je zaznamenaný horizont osídlenia Bronkivského hradu z 15. storočia, avšak v tom čase sa lokalita, pravdepodobne, používala ako sklad.

Archeologické nálezy nepotvrdili predpoklady bádatel'ov o neustálom obliehaní a útokoch na Vynohradivský hrad. V Koroleve je obliehanie hradu zaznamenané začiatkom 16. storočia. Aktívna činnost' na hrade Nyaláb pokračovala minimálne do začiatku 17. storočia. Ukončenie využívania Seredňanského hradu sa stanovuje na začiatok 18. storočia.

Vd’aka získaným materiálom v súčasnosti môžeme určit' tri základné horizonty výstavby hradov na sledovanom území. Prvá na konci 13. storočia (Bronka, Nevycké) a druhá na začiatku 14. storočia (Korolevo, Vynohradiv, Nevycké). Prvú etapu charakterizuje výstavba valcových veží, druhú výstavba gotických štvorhranných veží. Ich spoločnou črtou je malá plocha ohradená opevnením, ako aj slabý kultúrny horizont, ktorý naznačuje, že v tom čase bola dominantnou strážna funkcia. Situácia sa výrazne mení v druhej polovici 15. a na začiatku 16. storočia, ked' sa ako reakcia na rozsiahle šírenie strelných zbraní vykonáva rozsiahla reorganizácia existujúcich (Korolevo, Vynohradiv, Nevycké) a výstavba nových silných opevnení (Seredné). Ukončenie využívania hradov, okrem Užhorodského a Mukačivského, patrí do 17.-18. storočia.

Spolu s riešením základných problémov stratigrafie a chronológie pamiatok sú urobené prvé kroky pre analýzu materiálnej kultúry obyvatel’ov hradov. V tejto oblasti významnú pomoc poskytli slovenskí kolegovia: doktor J. Hunka - vyhodnotenie numizmatickej zbierky (HunkaProhnenko-Zsilenko 2017, 115-130; Прохненко-Жиленко 2016, 7-20; 2017, 141-156), doktor P. Piančak - vyhodnotenie osteologickej zbierky (Пьянчак-Прохненко 2008, 166-177), profesor L. Mihok - archeometalurgická analýza výrobkov vyrobených z čiernych kovov (Mihok-Prokhnenko 2008, 149-165; 2009, 261-273).

Na záver chceme poznamenat', že nálezy získané archeologickou expedíciou Užhorodskej národnej univerzity o dejinách hradov Zakarpatskej Ukrajiny výrazne spresňujú a doplňujú údaje o regionálnej podobe stredoveku a včasného novoveku. Pre reprezentáciu celistvého obrazu je však potrebný rozsiahly a účelný výskum synchrónnych pamiatok celého Horného Potisia.

\section{Pramene a literatúra}

A PERÉNYI: A Perényi Család Levéltára 1222-1526. Közzéteszi: Tringli István. Magyar országos Levéltár, MTA Történettudományi Intézet. Budapest 2008.

AO I: Anjoukori Okmánytár. Codex diplomaticus Hungaricus Andegavensis. I. (1301-1321). Budapest 1878. ÁÚO XII: Árpádkori Új Okmánytár. Codex diplomaticus Arpadianus continuatus. XII. Pest 1874.

BUDAI, É., 1814: Magyar Ország históriaja: A Mohatsi Veszedelemtöl fogva Buda viszszavételéig. Debrecen. CDH III/2: Codex Diplomaticus Hungariae Ecclesiasticus Ac Civilis. T. III/2. Budae 1829.

ENGEL, P., 1998: A nemesi társadalom a középkori Ung megyében. Budapest. 
EMŐDI, T., 2005: A beregszentmiklósi Telegdi-Rákóczi-kastély, Korunk 16. évf. №12, 38-42.

FÜGEDI, E., 1977: Vár és társadalom a 13-14. századi Magyarországon. Budapest.

GYÖRFFY, GY., 1987: Az Árpád-kori Magyarország történeti földrajza. I. 3. kiadás. Budapest.

HO: Hazai Oklevéltár 1234-1536. Budapest 1987.

HUNKA, J.-PROHNENKO, I.-ZSILENKO, M., 2017: A királyházai Nyaláb vár pénzérméi, Numizmatikai közlöny, CXIV-CXV, évfolyam 2015-2016, 115-130.

KARÁCSONYI, J., 1900: A magyar nemzetségek a XIV század közepéig, I köt. Budapest.

KRISTÓ, GY., 1986: Az Árpád-kor háborúi. Budapest.

LEHOCZKY, T., 1996: Bereg vármegye. Budapest - Bergszász.

MIHOK, L.-PROCHNENKO, I., 2008: Analysis of Iron Objects from Korolevo and Vinogradovo Castles, Carpatica-Карпатика 37, 149-165.

- 2009: Metallographic analysis of iron objects from castle Bronka, Transkarpathian Ukraine, Carpatica-Карпатика 38, 261-273.

PROHNENKO, I.-MOJZSESZ, V.-ZSILENKO, M., 2012: A királyházai vár csempekályhája, A nyíregyházi Jósa András Múzeum Évkönyve LIV, 241-285.

- 2013: Kárpátalja középkori és kora újkori várainak kutatsá, A nyíregyházi Jósa András Múzeum Évkönyve LV, 203-250.

PROHNENKO, I.-ZSILENKO, M., 2015: A királyházai Nyaláb vár, Várak kastélyok templomok, Évkönyv 2015, 68-71.

- 2016: Baranka vára, Várak kastélyok templomok, Évkönyv 2016, 77-79.

- 2016a: A királyházi Nyalábvár 2. helysége, Communicationes archaeologicae Hungariae 2015-2016, 325-379.

- 2017: A szerednyei vár kutatása, Várak kastélyok templomok, Évkönyv 2017, 56-59.

PROHNENKO, I.-ZSILENKO, M.-MOJZSESZ, V., 2016: Korolevo castle of Nyaláb, AH 41, 273-299.

RISKÓ, M., 2007: Ferencesek Nagyszőlősön. Budapest.

RUPP, J., 1872: Magyarország helyrajzi története fö tekintettel az egyházi intézetekre, II kötet. Pest.

TAKÁTS, S., 1928: Régi magyar kapitányok és generálisok. Budapest.

ZO: Zsigmondkori Oklevéltár I. (1387-1399). Budapest 1951.

МИКИТАСЬ, В.-ЧУЧКА, П., 1968: Дві Закарпатські оригінальні пам'ятки XV ст., Мовознавство 1, $62-64$.

ПРОХНЕНКО, И.-ГОМОЛЯК, Е.-ЗОМБОР, И., 2008: Середнянский замок, Сarpatica-Карпатика, Вип. 37, 189-192.

- 2009: Исследование замков Закарпатья, Саrpatica-Карпатика, Вип. 38, 239-260.

ПРОХНЕНКО, И.-ГОМОЛЯК, Е.-МОЙЖЕС, В., 2007: Результаты исследования Виноградовского и Королёвского замков в 2007 году, Carpatica-Карпатика 36, 219-255.

- 2008: Результаты исследования Броньковского замка, Саrpatica-Карпатика 37, 139-148.

- 2011: Результаты исследования замков Закарпатья, Satu Mare. Studii şi comunicări. Seria archeologie XXVII/I, 187-234.

- 2011 а: Результаты исследования Королёвского замка в 2011 году, Карпатика 40, 213-232.

ПРОХНЕНКО, И.-ЖИЛЕНКО, М., 2016: Королёвский замок Нялаб во владении потомков молдавского воеводы Caca, Tyragetia. Istorie. Muzeologie. Serie nouă, Vol. 10[XXV], nr. 2, 53-66.

ПРОХНЕНКО, И.-ЖИЛЕНКО, М.-МОЙЖЕС, В., 2013: Исследование Королёвского замка Нялаб в 2013 году, Карпатика, Вип. 42, 194-249.

ПРОХНЕНКО, И.-МОЙЖЕС, В.-ГОМОЛЯК, Е., 2011: Результаты исследования Королёвского замка в 2011 году, Карпатика, Вип. 40, 213-232.

ПРОХНЕНКО, И.-МОЙЖЕС, В.-ЖИЛЕНКО, М., 2012: Результаты исследования Королёвского замка Нялаб в 2012 году, Карпатика 41, 204-248.

ПРОХНЕНКО, І., 2014: Королівський замок Нялаб. В: Збірник матеріалів “Археологія \& Фортифікація України". IV Всеукраїнська науково-практична конференція Кам'янець-Подільського державного історичного музею-заповідника, приурочена 180-й річниці від дня народження Володимира Боніфатійовича Антоновича (1834-1908), Вип. 4, 234-243. Кам’янець-Подільський. 
- 2015: Кахляна піч 4 Королівського замку Нялаб. В: Збірник матеріалів, Археологія \& Фортифікація України, V Всеукраїнська науково-практична конференція, приурочена 125-й річниці заснування Кам'янець-Подільського державного історичного музею-заповідника, Вип. 5, 117-124. Кам'янець-Подільський.

- 2015а: Розкопки Королівського замку Нялаб, Археологічні дослідження в Україні 2014, 46-47.

- 2016: Кімната №3 Королівського замку Нялаб. В: Збірник матеріалів, Археологія \& Фортифікація України, VI Міжнародна науково-практична конференція Кам'янець-Подільського державного історичного музею-заповідника, присвячена 150-й річниці від дня народження Михайла Сергійовича Грушевського (1866-1934), Вип. 6, 150-156. Кам’янець-Подільський.

- 2016а: Дослідження Королівського замку Нялаб, Археологічні дослідження в Україні 2015, 38-41.

- 2016 b: Кахлі Королівського замку Нялаб. В: Хотинщина в період польсько-турецьких війн XVII століття (до 395-річчя Хотинської війни 1621 р.). Матеріали науково-практичної конференції, 122-142. Хотин.

-2017: Питання хронології Середнянського замку. В: Збірник матеріалів. “Археологія \& Фортифікація України”. VII Всеукраїнська науково-практична конференція Кам'янець-Подільського державного історичного музею-заповідника, присвячена 65 -й річниці від дня народження Миколи Борисовича Петрова (1952-2008) та 110-й річниці від дня народження Олега Ольжича (Олега Олександровича Кандиби) (1907-1944), 131-136. Кам'янець-Подільський.

ПРОХНЕНКО, І.-ГОМОЛЯК, О., 2007: Дослідження Виноградівського та Королівського замків у 2007 році. B: Relaţii româno-ucrainene. Istorie şi contemporaneitate. Румунсько-українські відносини. Історія та сучасність, 83-94. Cluj-Napoca - Satu Mare.

- 2009: До історії замків Закарпаття, Військово-історичний альманах 1(18), 71-97.

- 2013: Дослідження Королівського замку в 2011 р. В: Археологічні дослідження в Україні 2012, 170-171. Київ-Луцьк.

- 2013 а: Розкопки Королівського замку в 2012 р. В: Археологічні дослідження в Україні 2012, 171-172. Київ-Луцьк.

ПРОХНЕНКО, І.-ГОМОЛЯК, О.-ЗОМБОР, І., 2010: Дослідження замків Закарпаття у 2009 р. В: Археологічні дослідження в Україні 2009, 346-348. Київ-Луцьк.

ПРОХНЕНКО, І.-ГОМОЛЯК, О.-МОЙЖЕС, В., 2009: Результати дослідження Виноградівського і Королівського замків. В: Археологічні дослідження в Україні 2006-2007, 296-301, Київ.

ПРОХНЕНКО, І.-ЖИЛЕНКО, М., 2014: Розкопки Королівського замку Нялаб. В: Археологічні дослідження в Україні 2013, 134-135. Київ.

- 2016: Розвиток фальшивомонетництва на землях Північно-Східної Угорщини у XV-XVI століттях (за матеріалами замків Закарпаття), Науковий вісник Ужгородського університету. Серія: історія, Вип. 1(34), 7-20.

- 2016а: Зображення святого Христофора на кахлях Королівського замку Нялаб, Наукові записки Ужгородського університету. Серія: Історично-релігійні студії, Вип. 4, 131-142.

- 2017: Монети Королівського замку Нялаб, Записки отдела нумизматики и торевтики Одесского археологического музея III, 141-156.

ПРОХНЕНКО, І.-ЖИЛЕНКО, М.-МОЙЖЕС, В., 2016: Королівський замок Нялаб, Вісник Інституту археології, Вип. 11, 123-154.

ПРОХНЕНКО, І.-МОЙЖЕС, В.-ЖИЛЕНКО, М., 2013: Біблійні сюжети на кахлях Королівського замку, Наукові записки Ужгородського університету. Серія: історично-релігійні студії 2, 142-151. - 2013 а: Єзуїтський медальйон з Королівського замку, Наукові записки Ужгородського університету. Серія: історично-релігійні студії, Вип. 2, 152-163.

- 2014: Зображення святого Юрія на кахлях Королівського замку Нялаб, Наукові записки Ужгородського університету. Серія: Історично-релігійні студії, Вип. 3, 105-126.

- 2014а: Зображення герба Матяша Корвіна на кахлях Королівського замку, Satu Mare. Studii şi comunicări. Seria archeologie XXX/I, 259-271.

ПРОХНЕНКО, І.-МОРДОВІН, М., 2017: Товарні текстильні пломби Середнянського замку. В: Військово-політичний та соціально-економічний розвиток Середнього Подністров’я у середні віки 
та новий час. Матеріали науково-практичної конференції (м. Хотин, 29 вересня 2017 р.), 89-101. Хотин.

ПЬЯНЧАК, П.-ПРОХНЕНКО, И., 2008: Анализ остеологического материала замков северо-восточной части Верхнего Потисья, Саrpatica-Карпатика 37, 166-177.

\section{Summary}

\section{Research of the archaeological expedition of Uzhhorod National University into} Transcarpathian castles

Three main periods in the construction of medieval fortifications in the Transcarpathian Region were defined, based on reliable local finds. The first period, the late 13th century (Bronka, Nevytske and Silce) and the second one, mid-14th century (Korolevo, Khust and Nevytske) were connected with the construction of a network of castles in the Kingdom. of Hungary. Their construction was motivated by the threat coming from the south and took place under the conditions of the post-Mongolian economic revival. Round-shaped keeps were typical of the first period and square-shaped towers of the second one. Both periods are characterized by small territories including fortifications and short cultural horizons. This enables a discussion about their dominant and guarding function in this period.

The situation changed dramatically in the second half of the 15th - early 16th century when fire weapons became widespread. This triggered a massive reconstruction of the existing castles (Korolevo, Vynogradiv and Nevytske) and the construction of new, mighty fortifications (Seredne, Kvasovo). The castle in Bronka was used as a guard point at that time.

Most of the castles, except for Uzhhorod, Mukachevo and Khust, ceased to function in the 17 th-18th century.

doc. PhD. Igor Prokhnenko, Katedra archeológie, etnológie a kultúrnych štúdií Fakulty histórie a medzinárodnýchh vzt’ahov Užhorodskej národnej univerzity, Národná 3, Užhorod, 88 000, Ukrajina, prohnenkoigor@ukr.net

Maria Zhylenko, Archeologické múzeum Fakulty histórie a medzinárodnyh vzt’ahov Užhorodskej národnej univerzity, Národná 3, Užhorod, 88 000, Ukrajina, arhlabunu@ukr.net 